\title{
Pooling, Access, and Countervailing Power in Channel Governance
}

\author{
George Hendrikse
}

Forthcoming in Management Science

\begin{tabular}{|l|l|}
\hline \multicolumn{2}{|l|}{ ERIM REPORT SERIES RESEARCH IN MANAGEMENT } \\
\hline ERIM Report Series reference number & ERS-2011-009-ORG \\
\hline Publication & March 2011 \\
\hline Number of pages & 27 \\
\hline Persistent paper URL & http://hdl.handle.net/1765/22815 \\
\hline Email address corresponding author & ghendrikse@rsm.nl \\
\hline Address & Erasmus Research Institute of Management (ERIM) \\
& RSM Erasmus University / Erasmus School of Economics \\
& Erasmus Universiteit Rotterdam \\
& P.O.Box 1738 \\
& 3000 DR Rotterdam, The Netherlands \\
& Phone: + 31 10 408 1182 \\
& Fax: + 31 10 408 9640 \\
& Email: info@erim.eur.nl \\
& Internet: $\quad$ www.erim.eur.nl \\
\hline
\end{tabular}

Bibliographic data and classifications of all the ERIM reports are also available on the ERIM website: www.erim.eur.nl 


\section{ERASMUS RESEARCH INSTITUTE OF MANAGEMENT}

\section{REPORT SERIES}

\section{RESEARCH IN MANAGEMENT}

\begin{tabular}{|c|c|}
\hline \multicolumn{2}{|c|}{ ABSTRACT AND KEYWORDS } \\
\hline Abstract & $\begin{array}{l}\text { Fruit and vegetable marketing organization The Greenery has experienced various governance } \\
\text { structure changes, like horizontal merger, forward integration, and the emergence of grower } \\
\text { associations. A multilateral incomplete contracting model is presented to account for these } \\
\text { changes by analysing the interactions between pooling, access, and countervailing power. This } \\
\text { model does not only explain the changes at The Greenery, but it contributes also to the design of } \\
\text { efficient channel governance. }\end{array}$ \\
\hline Free Keywords & channel governance, cooperatives, pooling, foreclosure, market power, incomplete contracts \\
\hline Availability & $\begin{array}{l}\text { The ERIM Report Series is distributed through the following platforms: } \\
\text { Academic Repository at Erasmus University (DEAR), DEAR ERIM Series Portal } \\
\text { Social Science Research Network (SSRN), SSRN ERIM Series Webpage } \\
\text { Research Papers in Economics (REPEC), REPEC ERIM Series Webpage }\end{array}$ \\
\hline Classifications & $\begin{array}{l}\text { The electronic versions of the papers in the ERIM report Series contain bibliographic metadata } \\
\text { by the following classification systems: } \\
\text { Library of Congress Classification, (LCC) } \underline{\text { LCC Webpage }} \\
\text { Journal of Economic Literature, (JEL), JEL Webpage } \\
\text { ACM Computing Classification System CCS Webpage } \\
\text { Inspec Classification scheme (ICS), ICS Webpage }\end{array}$ \\
\hline
\end{tabular}




\title{
Pooling, Access, and Countervailing Power in Channel Governance
}

\author{
George Hendrikse ${ }^{1}$
}

(Forthcoming in Management Science)

\begin{abstract}
Fruit and vegetable marketing organization The Greenery has experienced various governance structure changes, like horizontal merger, forward integration, and the emergence of grower associations. A multilateral incomplete contracting model is presented to account for these changes by analysing the interactions between pooling, access, and countervailing power. This model does not only explain the changes at The Greenery, but it contributes also to the design of efficient channel governance.
\end{abstract}

Keywords: Channel Governance, Cooperatives, Pooling, Foreclosure, Market Power, Incomplete contracts.

\footnotetext{
${ }^{1}$ Rotterdam School of Management, Erasmus University, Office T8-56, P.O. Box 1738, 3000 DR Rotterdam, The Netherlands, ghendrikse@rsm.nl.
} 


\section{Introduction}

The Greenery B.V. is one of the leading companies in Europe in the fruit and vegetable sector. Its main activity is to provide a complete range of fruits and vegetables to supermarket chains in Europe, North America and the Far East throughout the year. Other major target groups are wholesale businesses, catering companies and industrial processing companies. The company has some 2,500 employees, while its shares are owned by 1500 producers. They are members of the horticultural cooperative The Greenery U.A. and they market all their products via The Greenery.

The Greenery has gone through various governance structure changes. It started as a merger between nine regional fruit and vegetable auction cooperatives in December 1996. They combined all their assets and activities into Voedingstuinbouw Nederland (VTN). VTN is the $100 \%$ shareholder of The Greenery. The Greenery integrated forward by acquiring the fresh produce wholesalers Dutch Van Dijk Delft Group and the Fresh Produce Division of Perkins Food plc, a UK based wholesaler in 1998 (Bijman 2002, p101). Various large growers left The Greenery to start product-specific bargaining associations during the next few years. Finally, various bargaining associations merged again with The Greenery after the introduction of member benefit programs.

These governance structure changes are not unique to The Greenery. The trend towards differentiation and innovation in marketing channels puts pressure on the relationship between the parties in the channel. One source of this development is the growing diversity in customer demands, increasing the importance of investments of the parties most close to the final consumers. This seems to favour governance structures allocating ownership to parties close to consumers. One of the responses has been that wholesalers start to contract directly with producers (Bijman 2002). Technological developments are another source of heterogeneity. Different classes of producers emerge based on meeting certain product and transaction requirements, like quality, transaction volume, and delivery time (Nilsson 1998). This favors governance structures allocating ownership to parties closer to primary producers. Examples are forward integration into wholesaling and producers establishing new organisations to bargain with wholesalers or retailers.

This article addresses the governance structure implications of these developments for producers as well as wholesalers. Some of these developments can be understood from the perspective of the complete contracting models in marketing (Anderson and Coughlan 2002, Coughlan and Wernerfelt 1989). They are informative regarding the details of specific contracts, but a different framework is more suited to address the nuances of the above governance structure changes in terms of ownership/decision rights. This contributes not only to the understanding of these changes, but also to the design of efficient channel governance. An incomplete contracting model will be developed to explain the governance structure changes at The Greenery (Grossman and Hart 1986; Hart and Moore 1990). The model will be tailored to the governance alternatives adopted by The Greenery in the course of time. The effect of the interactions between pooling, countervailing power, and access on the efficiency of various governance structures is addressed by answering the following question: Which governance structures result in efficient investments?

The article is organized as follows. Section 2 positions the model in the literature. Section 3 presents the model. Section 4 will formulate the outcomes of the model. The governance structure changes at The Greenery will be addressed from the perspective of the model in section 5. Section 6 concludes.

\section{Literature}

A standard way of characterizing a governance structure is to distinguish income and decision rights (Hansmann 1996). Decision rights in the form of authority concern all rights 
and rules regarding the deployment and use of assets. Income rights specify the rights to receive the benefits, and the obligations to pay the costs associated with the use of an asset, thereby creating the incentive system faced by decision makers. These two aspects of a governance structure will be illustrated with the governance structure of The Greenery. It is a producer cooperative. The core of a producer cooperative is member control over the infrastructure or assets at the downstream stage of production. Decision rights are therefore owned by an upstream party (vertical relationship), where the upstream party consists of an association of many independent growers (horizontal relationship). The Commission of the European Communities (2001, p12) formulates regarding the income rights of these cooperatives that they have 'an orientation to provide benefits to members and satisfy their needs, democratic goal setting and decision-making methods, special rules for dealing with capital and profit, and general interest objectives (in some cases)'. A prominent example of the 'special rules for dealing with capital and profit' is that most cooperatives and associations use a '... pooling arrangement in which members share equitably on a per-unit basis in the revenue stream that has been created...' (Cook and Iliopoulos 1999, p526). ${ }^{2}$

Income and decision rights are analysed in different branches of the field of contract theory (Bolton and Dewatripont 2005). The analysis of income rights / incentives is the realm of complete contracting theory in the form of agency relationships. The working hypothesis is that everything that is known, can and will be incorporated in the design of optimal remuneration schemes / contracts without costs. However, contracts are in general incomplete, due to the costs of writing contracts, the complexity of transactions, or the vagueness of language. Incomplete contracts are completed by the allocation of authority over assets in order to decide in circumstances not covered by the contract. Incomplete contracting theory addresses the allocation of decision power / authority in situations left open by formal (incentive) contracts.

The incompleteness of contracts causes problems when the parties involved in the exchange make specific, irreversible investments. Specificity of investments entails that the costs of the investment are paid always entirely by the investing party due to the noncontractibility of these costs. ${ }^{3}$ This will give rise to ex post opportunistic behaviour regarding the remaining surplus. ${ }^{4}$ The investor recognizes his weak bargaining position once the investment has been made, and may decide not to invest in the project generating the highest surplus. This is the (inefficient) hold-up problem (Klein et al., 1978). The value of an efficient governance structure is that it provides all parties with incentives to invest in such a way that the highest value is generated. It allocates sufficient bargaining power/strength (in terms of ownership over assets) to the investor that he is confident that the costs of investment can be recouped (Grossman and Hart 1986, Hart and Moore 1990). Trade-offs are involved in the determination of the efficient governance structure because allocating more ownership rights to one party means taking ownership rights away from another party.

The focus in this article is on the allocation of decision rights in the form of ownership over assets, while taking income rights into account. The model investigates the interactions between one decision right (priority access) and two income rights (pooling, countervailing power) on the incentive to invest for each party and the efficiency of various governance structures in an incomplete contracting model. These decision and income rights will be elaborated upon now. First, the desire to obtain a more certain demand by securing access has always been an important driving force in structuring the governance of enterprises and markets. For example, Nourse (1922, p581) observes already about 'a small fruit-producing

\footnotetext{
${ }^{2}$ This is also reflected in the definition of a cooperative of the U.S. Department of Agriculture (USDA 1993): 'A cooperative is a user-owned and controlled business from which the benefits are derived and distributed equitable on the basis of use.'

${ }^{3}$ Relevant examples regarding the case in this article are the outlays geared towards the development of specific fruit and vegetables.

${ }^{4}$ The perishability of fruits and vegetables is also vulnerable to opportunistic behaviour.
} 
section' that ' $\ldots$ the salvaging of their investment, or the continuance of their life work may be at stake on the part of growers. Hence it is argued (and demonstrated in practice) that the cooperative association of producers frequently achieves results where private outside entrepreneurship fails.' One of his arguments (p593) is that '... the agricultural producer can advantageously avail himself of the same cooperative form to open and maintain a channel from his farm to the factory or the wholesale or even the retail market ...'. Nowadays members delegate the formal authority regarding many aspects of the cooperative enterprise to the CEO, but this accompanied by granting each member the right, and also the obligation, to deliver a specified quantity of the commodity each season, i.e. access. Nilsson (1988, p42) describes its relevance by 'The delivery obligation for members is the dominating practice everywhere; in some countries it is even an obligation by law.' Direct access at the retail stage can be established by forward integration. Forwardly integrated growers have the decision power to direct the activities at the processor stage of production, i.e. the wholesaler has to buy the output of the owners of the cooperative.

Second, pooling is an important aspect in many organizations. Nilsson $(1998, \mathrm{p} 43)$ observes 'The principle of equal treatment within agricultural cooperatives is traditionally strong. This involves things as pricing, e.g., prices are not always differentiated based on quality and quantity, and member control, e.g., the general rule is that all members have equal voting rights.'. The importance of pooling is that revenues and costs are allocated to a certain extent independent of quantity and / or quality. The increasing grower heterogeneity poses also a challenge for traditional grower organizations because various aspects of these governance structures are tailored towards homogeneous members. Pooling will be referred to as the equality principle in this article. The equality principle will entail equal treatment regarding the distribution of revenues as well as the delivery of output. The equal sharing rule regarding the distribution of revenues means that each member receives the same remuneration for a unit of output that is delivered, regardless the quality of the product. ${ }^{5}$ The equal sharing rule regarding the delivery of output entails that customer demand is met by proportionally delivering from the output of each grower, regardless the quality.

Third, it matters for the price level in a market whether a monopolistic seller is facing a fragmented demand side or many small sellers (growers) facing a few large buyers (retailers). The latter situation is increasingly representative for many agricultural markets due to the massive consolidation of retailers (Reardon et al., 2004). It undermines the bargaining power of growers regarding the price of exchange. The balance of power between sellers and buyers can be restored by organizing countervailing power between many small parties (Galbraith, 1952) and drives some of the current governance structure changes. Having two upstream parties and one downstream party reflects that the concentration at the retail level entails usually that a retailer handles the products of various producers. Organizing countervailing power of the growers prevents that the wholesaler can deal with the growers separately. This is attractive for the growers in establishing a price with the wholesaler.

The positioning of this article in the literature is as follows. First, the characterization of a governance structure in terms of income and decision rights implies that the governance response to the trend towards differentiation and innovation in marketing channels can be twofold. First, enterprises may change their income rights by restructuring their bylaws. For example, producer cooperatives have changed their bylaws in order to address the free-rider problem, the horizon problem, the portfolio problem, the control problem, and the influence problem in an environment of increasing heterogeneity (Cook 1995). Second, a different allocation of decision rights may be needed in order to deal effectively and efficiently with the increasing heterogeneity between members. Examples are the emergence of grower associations and moving decision power closer to final product markets (Hendrikse and

\footnotetext{
${ }^{5}$ This is not at odds with the fact that many cooperatives, for instance, pay for quality. It is sufficient for the argument of this paper that some aspects of quality are not completely accounted for in the distribution of revenues.
} 
Veerman, 2001). The model in the next section highlights the second response.

Second, the model addresses the scope of the enterprise (Coase 1937) and is related to the subsequent literature on transaction costs economics (Williamson 1985), incentive systems (Holmstrom and Milgrom 1994), and hybrid forms (Makadok and Coff 2009). This literature is mainly concerned with bilateral relationships. However, channel relationships are usually multilateral. For example, when a number of sellers have to rely on a single source of demand, surpluses may make the sellers worry about (the price of) access at the downstream stage. This raises issues regarding the governance of horizontal as well as vertical relationships, i.e. the scope of the enterprise. The observation by Joskow (1989) that transaction costs analyses '... frequently ignore the possibility that there may be market power motivations or market power consequences for these organizational arrangements as well.' has therefore to be addressed. Another example is that governance structure choice often entails governance externalities, i.e. third parties may be affected by a switch in governance structure between two parties. This article addresses governance structure choice in a multilateral setting.

Third, the industrial organization literature formulates explanations for industry structure, including horizontal and vertical integration. Technological economies and market imperfections are important determinants in explaining industry structure in this literature (Perry 1989). ${ }^{6}$ The vast majority of the articles in this literature can be classified as income rights analyses, whereas this article takes a decision rights perspective.

Finally, the literature on marketing channel management assigns a prominent role to governance issues. Anderson and Coughlan (2002) distinguish seven governance structure issues in the organization of marketing channels. Their first issue is 'Vertical integration or not (whether to own the channel)'. This issue is at the core of this article. The incomplete contracting model of this paper can be viewed as a game theoretic treatment of channel ownership.

\section{Model}

This section presents an incomplete contracting, property rights model along the lines of Grossman and Hart (1986) and Hart and Moore (1990). The model studied is the simplest in which the issues of pooling, access, and countervailing power can arise: two upstream parties, offering produce of different quality in excess supply to one downstream party in a situation with certainty. ${ }^{7}$ Figure 1 depicts two types of growers and a wholesaler. A high quality grower generates value $\mathrm{A}$ and a low quality grower generates value $\mathrm{B}(<\mathrm{A})$. The source of this heterogeneity may reside in differences between growers in innovativeness, size, growth potential, and regional backgrounds. The high (low) quality grower will be referred to as grower 1 (2).

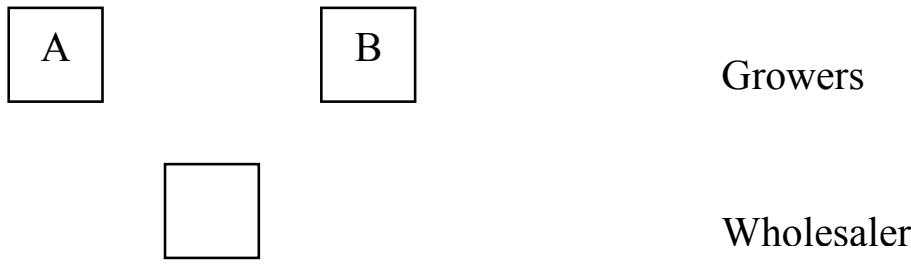

Figure 1: The three parties

\footnotetext{
${ }^{6}$ The marketing literature on dual distribution channels is advancing this research program (Balasubramanian 1998, Chiang et al. 2003, Liu and Zhang 2006, Purohit 1997, Zettelmeyer 2000).

${ }^{7}$ Bolton and Whinston (1993) is most related to this article. They also consider the choice of governance structure in a setting with multilateral trading relationships. Their model consists of one seller and two buyers; with some probability, upstream capacity is insufficient to satisfy downstream demand. Its main focus is on supply assurance concerns when several downstream firms are competing for inputs in limited supply.
} 
Assume that grower 1 (2) is able to produce one unit with value A (B). Define $x_{i}$ as the investment by grower $i$, where $i=1,2$. Each grower is assumed to take an all or nothing decision regarding investment, i.e. $x_{i}=0$ when grower $i$ does not invest and $x_{i}=1$ when grower $\mathrm{i}$ invests. The costs of the (specific) investment of grower 1(2) is defined as $\mathrm{k}_{1}\left(\mathrm{k}_{2}\right)$. The wholesaler demands at most one unit in total, but can spread its demand across the two producers. It is assumed that the wholesaler is essential for the growers to bring their produce to value.

Five governance structures regarding the allocation of asset ownership over these three parties are distinguished in figure 2. A cross in a box indicates that this party has power / authority to decide regarding its assets. ${ }^{8}$ Governance structure I represents market exchange, i.e. the growers and the wholesaler are independent. The association of all growers is represented by governance structure II. A producer cooperative is an association of many independent growers (horizontal relationship) who jointly own a downstream processor / retailer (vertical relationship). An association is the same as a producer co-operative, except for the vertical relationship. Figure 2 distinguishes producer three cooperatives (III, IV, and V), depending on the number and type of growers owning the downstream party. ${ }^{910}$

$\otimes$

\section{凶}

I Market exchange

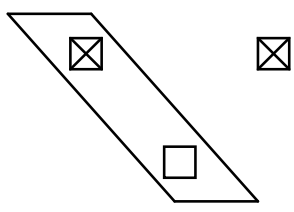

III High quality producer cooperative

\section{$\nabla \quad \nabla$}

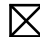

II Association

$凶$

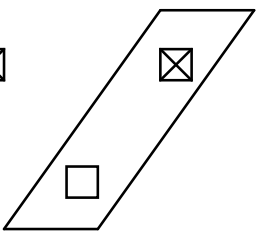

IV Low quality producer cooperative

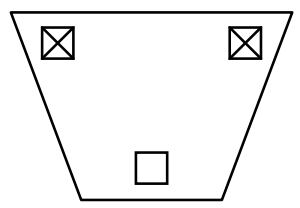

V Heterogeneous producer cooperative

Figure 2: Five governance structures

\footnotetext{
${ }^{8}$ Notice that other governance structures can be distinguished. For example, governance structure without authority for one or both growers. We don't consider these governance structures due to transparancy and length considerations.

9 A cooperative is usually conceived of as an organization consisting of many independent producers / consumers jointly owning an enterprise at another stage of production. This seems to be at odds with figure 2 , where the authority in a cooperative seems to be allocated to either one or two growers. However, this is not problematic for the model. It can be shown that many identical producers / consumers will always prefer a governance structure in which they are united above a governance structure in which they are all independent, ceteris paribus. Countervailing power drives this result. Each box in figure 1 can therefore be thought of as one grower, or as an association of many identical growers.

${ }^{10}$ The governance structures III and IV may also be viewed as a dual distribution market structure. Multiple channels of distribution have been studied before, like the coexistence of spot and contract markets in many agricultural markets (Hendrikse 2007), and the marketing literature on dual distribution channels (footnote 5).
} 
Table 1 distinguishes the governance structures by their decision rights in terms of ownership/authority over assets (figure 2) and priority access. Priority access of a grower means that the wholesaler is not allowed to reject the produce of this grower.

\begin{tabular}{|c|c|c|c|c|c|}
\hline $\begin{array}{c}\text { Governance } \\
\text { structure }\end{array}$ & $\begin{array}{c}\text { Authority } \\
\text { grower 1 }\end{array}$ & $\begin{array}{c}\text { Authority } \\
\text { grower 2 }\end{array}$ & $\begin{array}{c}\text { Authority } \\
\text { wholesaler }\end{array}$ & $\begin{array}{c}\text { Priority } \\
\text { access } \\
\text { grower 1 }\end{array}$ & $\begin{array}{c}\text { Priority } \\
\text { access } \\
\text { grower 2 }\end{array}$ \\
\hline I & Yes & Yes & Yes & No & No \\
\hline II & Yes & Yes & Yes & No & No \\
\hline III & Yes & Yes & No & Yes & No \\
\hline IV & Yes & Yes & No & No & Yes \\
\hline V & Yes & Yes & No & Yes & Yes \\
\hline
\end{tabular}

Table 1: Decision rights in the five governance structures

Once production costs are sunk, the active producer(s) negotiate with a monopoly wholesaler. Following Hart and Moore (1990), the outcome of negotiations between independent firms is assumed to be the Shapley value. ${ }^{11}$ It captures the implications of authority, the equality principle, countervailing power, and priority access for the distribution of bargaining power. The Shapley value determines a value for each player in each governance structure for all combinations of investment decisions. It serves to specify the revenue part of the payoffs in the two stage non-cooperative game, and therefore the incentive to invest. It depends on the choice of governance structure $\mathrm{G}$ and the choice of investment $\mathrm{X}$ by the growers, where $\mathrm{G}=\mathrm{I}, \mathrm{II}, \mathrm{III}, \mathrm{IV}, \mathrm{V}$ and $\mathrm{x}=\left(\mathrm{x}_{1}, \mathrm{x}_{2}\right)$. Table 2 presents the distribution of revenues in each governance structure when both growers invest. This is done for all possible investment choices in every governance structure in appendix 1.

\begin{tabular}{|c|c|c|c|c|}
\hline $\mathbf{x}$ & $\mathbf{G}$ & $\begin{array}{c}\text { Shapley value } \\
\text { grower 1 }\end{array}$ & $\begin{array}{c}\text { Shapley value } \\
\text { Grower 2 }\end{array}$ & $\begin{array}{c}\text { Shapley value } \\
\text { wholesaler }\end{array}$ \\
\hline \hline$(1,1)$ & I & $(3 \mathrm{~A}-2 \mathrm{~B}) / 6$ & $\mathrm{~B} / 6$ & $(3 \mathrm{~A}+\mathrm{B}) / 6$ \\
\hline$(1,1)$ & II & $(\mathrm{A}+\mathrm{B}) / 8$ & $(\mathrm{~A}+\mathrm{B}) / 8$ & $(\mathrm{~A}+\mathrm{B}) / 4$ \\
\hline$(1,1)$ & III & $\mathrm{A}$ & 0 & 0 \\
\hline$(1,1)$ & IV & 0 & $\mathrm{~B}$ & 0 \\
\hline$(1,1)$ & V & $(\mathrm{A}+\mathrm{B}) / 4$ & $(\mathrm{~A}+\mathrm{B}) / 4$ & 0 \\
\hline
\end{tabular}

Table 2: Distribution of revenues in each governance structure when both growers invest

Two remarks regarding table 2 will be formulated in order to highlight the various forces in the model. First, when both upstream producers are part of the heterogeneous cooperative (V) or form an association without the wholesaler (II), they share revenues equally. This reflects the equality principle. It entails that the revenues of the growers have to be shared equally over the parties jointly owning the assets when they both produce. Grower 1 and grower 2 earn the same in governance structure II and V when they both invest due to the aspect of pooling of revenues of the equality principle.

Second, notice that the decision rights of governance structures I and II are identical in

\footnotetext{
${ }^{11}$ The Shapley value (Shapley 1953) is an equilibrium concept in cooperative game theory. The tool of cooperative game theory is used to translate the various features of the model into numbers. A cooperative game is summarised by the characteristic function $(\mathrm{N}, \mathrm{v})$, where $\mathrm{N}$ is the set of players and $\mathrm{v}$ specifies a payoff for every possible subset of the set of players. The characteristic function determines the way in which the revenues are allocated to the three parties. The Shapley value is a vector consisting of the average value added of each player in every possible realization of the grand coalition of players.
} 
table 1. However, governance structures I and II differ in terms of total revenue as well as the distribution of the revenues. The total revenue (A) generated in governance structure $\mathrm{I}$ is larger than the total revenue $((\mathrm{A}+\mathrm{B}) / 2)$ generated in governance structure II. This is due to the aspect of pooling of deliveries of the equality principle in governance structure II. ${ }^{12}$ The difference in the payoff of growers 1 and 2 is also due to the lack of countervailing power and the presence of a bilateral monopoly to a certain extent (due to member heterogeneity) in governance structure I. Consider the lack of countervailing power in governance structure I. Supposing that there is no member heterogeneity, i.e. $\mathrm{A}=\mathrm{B}$. Each grower in governance structure I will receive $1 / 6$ of the surplus, while the wholesaler receives $2 / 3$. Each grower in governance structure II will receive $1 / 4$ of the surplus, while the wholesaler receives $1 / 2$. Governance structure I, i.e. the situation of most intense competition between the growers and therefore the lack of countervailing power, is most beneficial for the wholesaler. Consider next the bilateral monopoly feature of governance structure I. The difference between A and $\mathrm{B}$ represents the uniqueness of grower 1 . This is beneficial for grower 1 , but goes at the expense of grower 2 as well as the wholesaler. If the difference between the growers becomes very large, then the market is close to a bilateral monopoly. Grower 1 and the wholesaler capture each almost half of the surplus, while grower 2 receives almost nothing. ${ }^{13}$ Figure 3 presents the subgame when governance structure I is adopted in the first stage. ${ }^{14}$ These costs are assumed to be non-contractible and sunk, i.e. they are not recoverable in an alternative use, and are paid entirely by the investor. The subgames regarding the other four governance structures are presented in appendix 1.

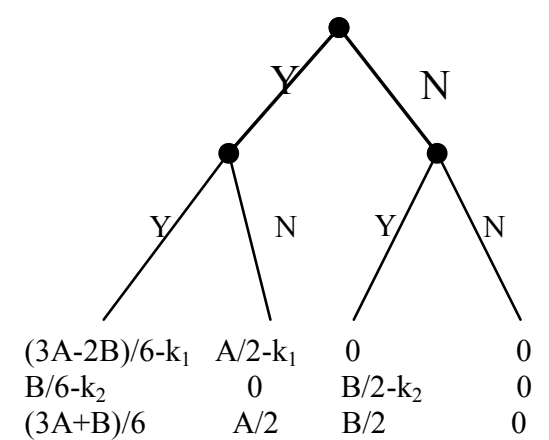

Figure 3: Subgame when governance structure I is adopted

\section{Grower 1}

Investment choice

\section{Grower 2}

Investment choice

Payoff grower 1

Payoff grower 2

Payoff wholesaler

\section{Efficient governance structures}

The standard incomplete contracting model consists of a two stage non-cooperative game: a governance structure stage and an investment stage (Grossman and Hart 1986, Hart and Moore 1990). The relationship between the stages is that the choice of governance structure in the first stage determines the incentive to invest in non-verifiable actions of each

\footnotetext{
${ }^{12}$ The equality principle is also present in governance structure I, but in a generic way. There is no averaging of payoffs of different types of growers, because there is no collective ownership of assets by different types of growers.

${ }^{13}$ Notice that this reasoning provides also the motivation for restricting our analysis to one grower 1 and one grower 2. Taking $\mathrm{A}=\mathrm{B}$ and comparing the governance structures I and II immediately reveals that identical growers increase their Shapley value by merging. More general, suppose that there are $\mathrm{n}$ identical growers, one wholesaler, and the surplus to be divided is 1 . The Shapley value is equal to $(1 / \mathrm{n}(\mathrm{n}+1), 1 / \mathrm{n}(\mathrm{n}+1), \ldots, 1 / \mathrm{n}(\mathrm{n}+1)$, $\mathrm{n} /(\mathrm{n}+1))$ when the growers are independent, while the Shapley value is $(1 / 2 n, 1 / 2 n, \ldots, 1 / 2 n, 1 / 2)$ when the growers are integrated.

${ }^{14}$ We assume regarding the second stage of the game that grower 1 decides before grower 2 . If grower 2 invests first, then the market is sometimes pre-empted. However, the main results continue to hold when this sequence of investment decisions is adopted.
} 
party in the second stage. To be more specific, a party is willing to deteriorate its bargaining position by making costs of specific investments in the second stage when the governance structure in the first stage of the game allocates sufficient bargaining power to this party to recoup its costs of investment in the ex post bargaining process.

Appendix 2 determines the subgame perfect equilibrium investment choices in the second stage of the game. There is a straightforward general pattern in the investment decisions. If $\mathrm{k}_{1}$ and $\mathrm{k}_{2}$ are sufficiently small, then both growers invest in several governance structures. Similarly, if both $\mathrm{k}_{1}$ and $\mathrm{k}_{2}$ are large then both growers don't invest. If $\mathrm{k}_{1}$ is relatively small and $\mathrm{k}_{2}$ is large, then grower 1 invests and grower 2 does not invest. The reverse also holds. ${ }^{15}$

An efficient governance structure entails that only one grower invests. ${ }^{16}$ The identity of this grower is determined by the investment generating the highest surplus, i.e. $\max \left\{0, \mathrm{~A}-\mathrm{k}_{1}\right.$, $\left.\mathrm{B}-\mathrm{k}_{2}\right\}$. Investment by grower 1 is efficient when $\mathrm{k}_{2}>\mathrm{k}_{1}+\mathrm{B}-\mathrm{A}$ and $\mathrm{k}_{1}<\mathrm{A}$. Investment by grower 2 is efficient when $\mathrm{k}_{1}>\mathrm{k}_{2}+\mathrm{A}-\mathrm{B}$ and $\mathrm{k}_{2}<\mathrm{B}$. It is efficient that nobody invests when $\mathrm{k}_{1}>\mathrm{A}$ and $\mathrm{k}_{2}>\mathrm{B}$. Efficiency of a governance structure depends on the values of $\mathrm{A}$ and $\mathrm{B}$, and the costs of specific investments. Many cases have to be distinguished, which is done in appendix 3 . The results of this appendix are summarized in figure 4. The values of $\mathrm{X}, \mathrm{Y}$ and $\mathrm{Z}$ are defined in appendix 3. The notation I/II (I/V) in this figure means that either I or II (I or V) is efficient, which depends on the values of $\mathrm{X}, \mathrm{Y}$ and $\mathrm{Z}$.

\footnotetext{
15 There are a few exceptions within this general pattern. For example, low quality grower 2 will switch in governance structure I from not investing when $\mathrm{k}_{1}<\mathrm{A} / 2$ and $\mathrm{B} / 6<\mathrm{k}_{2}<\mathrm{B} / 2$ to investing when $\mathrm{k}_{1}>\mathrm{A} / 2$ and $\mathrm{B} / 6<\mathrm{k}_{2}<\mathrm{B} / 2$. The reason is that grower 1 invests when $\mathrm{k}_{1}<\mathrm{A} / 2$, while grower 1 is not investing when $\mathrm{k}_{1}>\mathrm{A} / 2$. The switch from a competitive situation for grower 2 when $\mathrm{k}_{1}<\mathrm{A} / 2$ to a bilateral monopoly when $\mathrm{k}_{1}>\mathrm{A} / 2$ increases the payoff to such an extent that investment becomes attractive.

Grower 2 will switch in governance structure III from not investing when $\mathrm{k}_{1}<\mathrm{A}$ and $\mathrm{k}_{2}<\mathrm{B} / 2$ to investing when $\mathrm{k}_{1}>\mathrm{A}$ and $\mathrm{k}_{2}<\mathrm{B} / 2$. Grower 2 faces foreclosure due to priority access in governance structure III when grower 1 produces. However, if the costs of investment are above A, then grower 1 will not invest. This provides the opportunity for grower 2 to produce. Grower 1 will receive half of the revenues due to its control over the wholesale channel.

Finally, grower 2 will not invest in governance structure IV when $\mathrm{k}_{1}<\mathrm{A} / 2$ and $\mathrm{k}_{2}>\mathrm{B}-\mathrm{A} / 2$. Grower 2 will not invest despite ownership of the wholesaler because receiving half of the revenues of grower 1 due to having authority over the assets of the wholesaler is more attractive than investment.

${ }^{16}$ The classic motivation for the focus on efficient governance structures is that competitive processes are likely to winnow out the inefficient governance structures (Alchian 1950). A more recent motivation is provided by Wernerfelt (1994). He proposes an efficiency criterion for marketing design. It entails that ' ... parties in vertical trading relationships allocate their efforts towards marketing and information exchange such that no other arrangement makes them all better off.'
} 


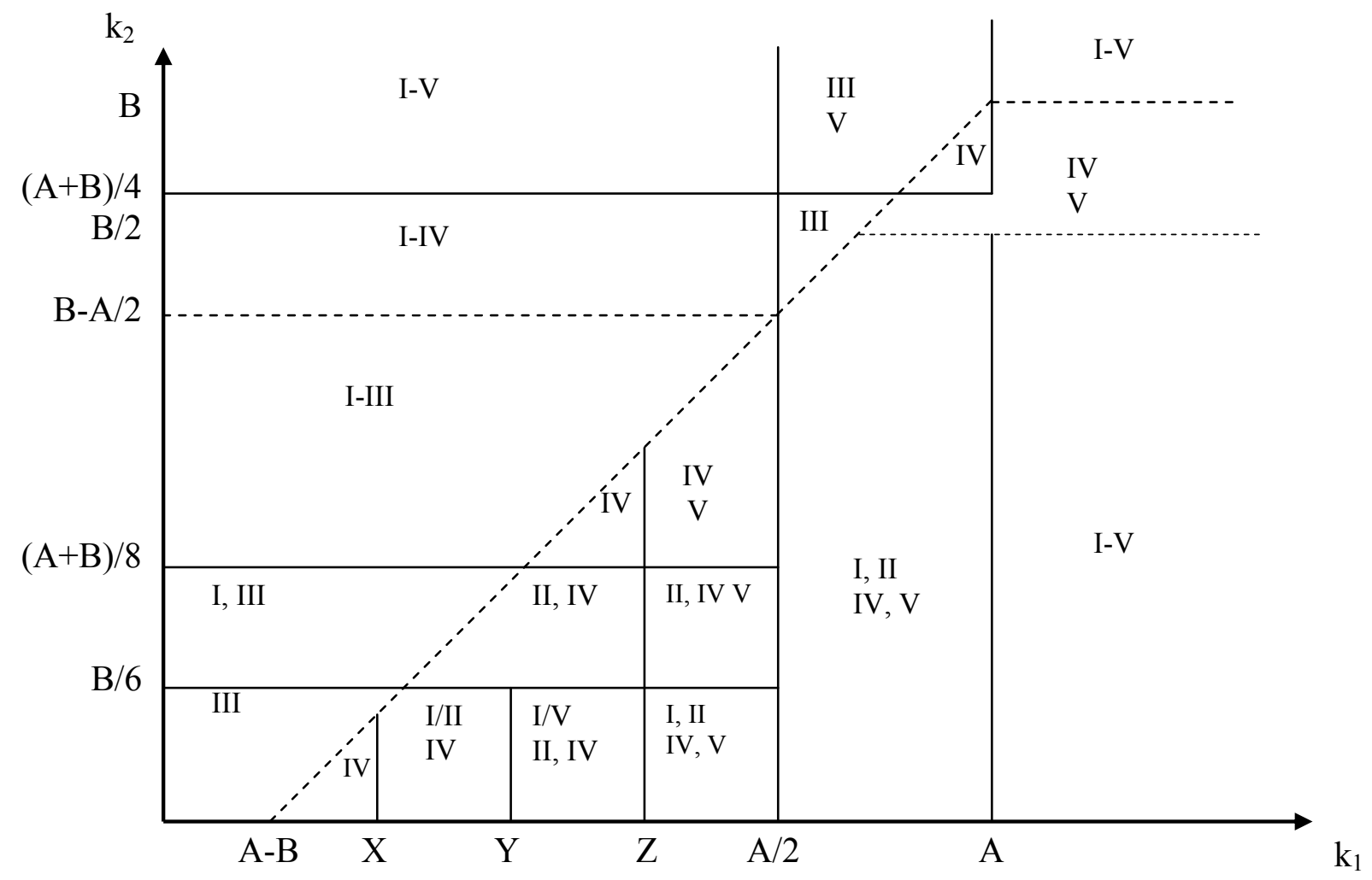

Figure 4: Efficient governance structures

Several observations regarding figure 4 will now be formulated. There are three observations regarding inefficient governance structures. First, there are various governance structures resulting in underinvestment, i.e. no grower produces. If $k_{1}$ is close to $A$ and $k_{2}$ is close to B, then neither grower 1 nor grower 2 will invest in the governance structures I and II. The main source of the inefficiency is that the wholesaler has too much power. Second, there is overinvestment in the governance structures I, II, and V when $\mathrm{k}_{1}$ and $\mathrm{k}_{2}$ are small. Both growers invest because the incentive to invest is too strong. This is inefficient because the processor can handle only one product. ${ }^{17}$

Third, there are governance structures in which exactly one grower is producing, but it is the wrong grower from an efficiency perspective. There are three sources of this inefficiency. Priority access of the inefficient grower deteriorates the incentive to invest of the efficient grower. This occurs in the governance structures III and IV for certain ranges of the parameter values. For example, only grower 1 invests in governance structure III due to access priority when $\mathrm{A} / 2<\mathrm{k}_{1}<\mathrm{A}$ and $\mathrm{k}_{2}<\mathrm{B} / 2$. The lack of countervailing power in governance structure in governance I reduces the revenues of grower 2 to such an extent that investment is not profitable anymore when the costs of investment are above $\mathrm{B} / 6$. Pooling in governance structure II is attractive for grower 2 in terms of revenues, but it is not sufficient to cover the costs of investment when $\mathrm{k}_{2}>(\mathrm{A}+\mathrm{B}) / 8$.

\footnotetext{
${ }^{17}$ Overinvestment, i.e. the practice of producing and not selling, is inefficient. It seems therefore counterfactual, but it emerges in some governance structures as equilibrium outcome due to the wrong incentives of the governance structure. It occurs in two ways in our model. First, the Shapley value accounts for all possible sequences of the emergence of the grand coalition. If both growers invest, then there is always one seller too 'late' to satisfy the demand for one unit of the wholesaler. However, selling once in a while may be sufficiently attractive to cover the costs of investment. This occurs in the governance structures I for certain ranges of the parameter values. Second, the equality principle in the governance structures II and V is responsible for taking half of the produce of each grower when both growers invest. The second half of the produce of each grower is destroyed in order to maintain sufficiently high prices in the market. This practice occurred at many auctions around Europe.
} 
Four observations are formulated regarding efficient governance structures. First, an efficient governance structure provides sufficiently strong incentives for the efficient grower to invest and sufficiently weak incentives for the inefficient grower to not invest. Sufficiently weak incentives are provided to the inefficient grower by allocating priority access to the efficient grower, i.e. governance structure III or IV. This results hold for all costs of investment. To be more specific, the choice of efficient governance structure to the north-west of the $45^{\circ}$ line entails that grower 1 invest and grower 2 does not. Governance structure III is always efficient because no power is allocated to grower 2. Similarly, governance structure IV is efficient to the south-east of the $45^{\circ}$ line in figure 5 because grower 2 invest and grower 1 does not. Grower 1 will not invest in governance structure IV regardless the costs of investment, because no power is allocated to grower 1. Governance structure III or IV is therefore always efficient.

Second, efficiency requires that only grower 2 invests when $\mathrm{k}_{1}>\mathrm{A}$ and $\mathrm{B} / 2<\mathrm{k}_{2}<\mathrm{B}$. Grower 1 will not invest because the costs of investment are too high. Grower 2 needs strong incentives to invest because the costs of investment are high. Governance structures IV (priority access) and $\mathrm{V}$ (equality principle and control over the wholesaler) allocate sufficient power to grower 2 to induce investment. Similarly, if $A / 2<k_{1}<A$ and $k_{2}>(A+B) / 4$, then governance structures III (priority access) and V (control over the wholesaler) will elicit investment by grower 1 only. Third, grower 1 will not invest when $k_{1}>A$ and $k_{2}<B / 2$. All governance structures giving some power to grower 2 will result in the efficient outcome. Similarly, if $\mathrm{k}_{1}<\mathrm{A} / 2$ and $\mathrm{k}_{2}>(\mathrm{A}+\mathrm{B}) / 4$, then grower 2 will not invest. All governance structures result in the efficient investment by grower 1 .

Fourth, governance structure IV is efficient to the north-west of the $45^{\circ}$ line when $\mathrm{k}_{2}>\mathrm{B}$ $\mathrm{A} / 2$. Grower 2 will not invest despite having all the power because owning the wholesaler results in half of the revenues of grower 1 without making the costs $k_{2}$ of investment.

\section{Governance structure changes at The Greenery}

The Greenery is the outcome of a merger between nine regional fruit and vegetable auction cooperatives. The timing is informative regarding the driving force behind this governance structure change. The Netherlands did not have a competition authority to enforce anti-trust laws before 1997. The dutch parliament decided that it had to be erected. In 1997 preparations were made to start its activities in january 1998. In December 1996 the merger of the nine auctions was concluded to prevent the possibility that it might be rejected by the new competition authority as a too powerful player in the market. In terms of our model, the merger is a shift from governance structure I to governance structure II. The Greenery establishes countervailing power for the fragmented growers in a market where the wholesale / retail stage of production has been consolidating. It entails a redistribution of payoffs from the processor to the growers. The growers receive half of the quasi-surplus in governance structure II, while it is less in governance I. If $\mathrm{A}$ is close to B, then both growers benefit from a switch from governance structure I to governance structure II.

The trend that consumers ask more variety and higher quality has induced some growers to innovate, therefore increasing member heterogeneity. This is reflected on the one hand in a higher level of A due to the willingness of consumers to pay more for higher quality, and on the other hand in a higher level of $\mathrm{k}_{1}$ due to the increased efforts / costs of innovation. Increasing heterogeneity creates problems in a heterogeneous association. Pooling limits the payoff received by innovative growers for their innovative efforts. One way to increase the reward for all growers in a heterogeneous association is to increase their market power even more. This was done by forward integration. The Greenery established forward integration by acquiring the fresh produce wholesalers Dutch Van Dijk Delft Group and the Fresh Produce Division of Perkins Food plc, a UK based wholesaler (Bijman 2002, p101), in order to start direct trade with major food retailers. It constitutes a switch from governance structure II to 
governance structure $\mathrm{V}$.

However, heterogeneous cooperatives have difficulties in keeping highly innovative growers. Some large growers left due to '... cross-subsidization of small growers' (Bijman and Hendrikse 2003, p102). Innovative growers started product-specific bargaining associations. There were also some innovative growers leaving the cooperative in order to form bargaining associations and marketing cooperatives to advance their specific interests. They felt that marketing efforts could be improved to highlight their products. It is reflected in our model by a higher level of A. The self-selection of innovative growers into grower associations represents the shift from governance structure $\mathrm{V}$ to governance structure IV. ${ }^{18}$ The disadvantage of governance structure IV for the innovative growers is that they don't control the infrastructure at the downstream stage anymore, and therefore have to pay a price for this loss of control. However, they are willing to pay this price because they escape the pooling aspect of the cooperative.

Nowadays, many cooperatives try to counter this process of adverse selection by spending considerable effort in developing member benefit programs. Different classes of members are distinguished based on meeting certain transaction requirements, like transaction volume, quality of produce, and delivery time. Differentiation occurs regarding cash payments as well as capital titles. Cooperatives with strong incentive structures are characterized by 'individualized' rather than collective capital structures (Nilsson 1998). The introduction of member benefit programs increases the number and extent of quality attributes covered by specific clauses in incentive contracts. The effect is that accounting for the heterogeneity of members in payment schemes reduces the heterogeneity between the members in the quality attributes / dimensions which are left unspecified by formal contracts. The introduction of member benefit programs entails from an incomplete contracting perspective that a smaller difference between A and B has to be governed. In terms of governance structures, a member benefit program reduces the negative impact of the equality principle for the high quality growers in the governance structures II and V. Innovative growers do not leave The Greenery anymore, or even come back to The Greenery. Innovative growers coming back to The Greenery is an example of a switch from governance structure IV back to governance structure $\mathrm{V}$.

Notice the contrast between a complete contracting principal-agent model and the above incomplete contracting analysis. The focus of a complete contracting analysis would be on monetary rewards for the provision of incentives, where the optimal contract satisfies incentive compatibility, participation, and renegotiation proofness constraints. The completeness aspect of the analysis is reflected in the compensation package being contingent on all observable contingencies. Incomplete contracting analyses start with the observation that not all future events can be described in a binding contract. Many decisions and transactions are left open to be determined later. This shifts the focus away from incentive issues on compensation contingent on outcomes to procedural and institutional design issues. The control variables become ownership titles, control rights, decision making rules, discretion, tasks, authority, and the like, to be allocated among contracting parties. It allows for addressing the costs and benefits of integration and the boundaries of the firm, and therefore the structure of marketing channels. Integration strengthens the investment incentives of the owner of the newly integrated firm, but the previous owner's bargaining position is weakened.

\section{Conclusions and further research}

????????????

\footnotetext{
${ }^{18}$ This process is not unique to The Greenery. During a few years 75 grower associations have emerged (Bijman 2002).
} 
The trend towards differentiation and innovation has resulted in changes in the governance structure of marketing channels. Economic and organizational factors determine the efficient governance structure (Hansen and Wernerfelt 1989), but these factors differ in attractiveness for the various players. The forces of pooling, access, and countervailing power have been highlighted regarding The Greenery. Growers like countervailing power and priority access, while the high quality grower and the wholesaler like self-selection. All player likes more authority, which sometimes creates a positive governance externality for the grower outside the hierarchical relationship. Increasing member heterogeneity induces forward integration and subsequently the emergence of dual distribution governance structures, while the introduction of member benefit programs reverses this development to a certain extent.

One of the results from the model is that one of the dual distribution governance structures is always efficient, but other governance structures may be efficient as well. The inefficiency of other governance structures is due to either underinvestment caused by the wholesaler having too much power, or overinvestment caused by the distribution of power being too dispersed, or investment by the inefficient grower due to priority access, lack of countervailing power, or pooling.

Future research may be pursued in various directions. First, a simplifying assumption of the model is that the wholesaler does not invest. However, this assumption may not be very restrictive because the wholesaler is already essential in the model. Second, the focus has been on efficient governance structures. Efficiency is an important consideration in the emergence and survival of governance structures, but strategic considerations play also a role in governance structure choice.

Third, a more restrictive assumption is that only the allocation of ownership is considered. Ownership is crude instrument to align interests. Many cooperatives spend nowadays considerable effort in redesigning their income rights in terms of developing member benefit programs. Examples are quantity discounts, quality premiums, service at cost, offering favourable possibilities to supply financial funds for specific members, and supplying services tailored to the broader interests of specific members. It is in line with the normative implication of the increasing heterogeneity for the efficiency of traditional cooperatives that the impact of the collective features has to be reduced.

Fourth, game theoretic models have often multiple equilibria for various ranges of the parameter values. Sutton (1990) proposes a bounds approach to deal with this multiplicity in empirical research. Two approaches are adopted. First, a focus on a single market allows for adding more details, and therefore reducing the number of equilibria. The Greenery is an illustration. Second, results may be formulated which hold across a broad class of industries. It entails excluding as many outcomes as possible as equilibrium outcomes, e.g. based on the incentive considerations outlined in the above model. The focus is on which governance structures disappear due to changes in the exogenous parameters.

Finally, the interaction between complete and incomplete contracting is important for assessing the impact of the trend towards differentiation and innovation on the choice of governance structure. ${ }^{19}$ The standard modeling of complete and incomplete contracts represent two extremes (Bajari and Tadelis 2001). The cost of specifying an additional state of nature in complete contracting models is zero, whereas it is infinite in incomplete contracting models. Most realistic is that positive, finite costs are incurred by specifying an additional contractual clause, which may have an impact on the choice of governance structure.

\section{References}

\footnotetext{
${ }^{19}$ Holmström and Milgrom (1994) have addressed have addressed the complementarity between complete and incomplete contracting. They are complementary because the focus is on allocating authority in situations not covered by formal contracts. Makadok and Coff (2009) is also relevant.
} 
Alchian, A.A. 1950. Uncertainty, evolution and economic theory. Journal of Political Economy 58(3) 211-221.

Anderson, E., A.T. Coughlan. 2002. Channel management: structure, governance, and relationship management. B.A. Weitz, R. Wensley, eds. Handbook of marketing, Sage, London.

Bajari, P., S. Tadelis. 2001. Incentives versus transaction costs: a theory of procurement contracts. RAND Journal of Economics 32(3) 387-407.

Balasubramanian, S. 1998. Mail versus mall: a strategic analysis of competition between direct marketers and conventional retailers. Marketing Science 17(3) 181-195.

Bijman, W.J.J. 2002. Essays on Agricultural Co-operatives; Governance Structure in Fruit and Vegetable Markets. PhD Thesis, Rotterdam School of Management, Erasmus University Rotterdam.

Bijman, W.J.J., G.W.J. Hendrikse. 2003. Co-operatives in chains: institutional restructuring in the dutch fruit and vegetable industry, Journal of Chain and Network Science 3(2) 95107.

Bolton, P., M. Dewatripont. 2005. Contract Theory. MIT Press, London.

Bolton, P., M.D. Whinston. 1993. Incomplete contracts, vertical integration, and supply assurance. Review of Economic Studies 60(202) 121-148.

Chiang, W. K., D. Chajed, J. D. Hess. 2003. Direct marketing, indirect profits: a strategic analysis of dual-channel supply-chain design. Management Science 49(1) 1-20.

Coase, R.H. 1937. The nature of the firm. Economica 4 386-405.

Cook, M.L. 1995. The future of U.S. agricultural cooperatives: a neo-institutional approach. American Journal of Agricultural Economics 77 1153-1159.

Cook, M.L., C. Iliopoulos. 1999. Beginning to inform the theory of the cooperative firm: emergence of the new generation cooperative, The Finnish Journal of Business Economics 4 525-535.

Commission of the European Communities. 2001. Co-operatives in Enterprise Europe. Brussels.

Coughlan, A.T., B. Wernerfelt. 1989. On credible delegation by oligopolists: a discussion of distribution channel management. Management Science 35(2) 226-239.

Galbraith, J.K. 1952. American Capitalism: The Concept of Countervailing Power. Houghton-Mifflin, Boston.

Grossman, S.J., O.D. Hart. 1986. The costs and benefits of ownership: a theory of vertical and lateral integration. Journal of Political Economy 94(4) 691-719.

Hansen, G.S., B. Wernerfelt. 1989. Determinants of firm performance: the relative importance of economic and organizational factors. Strategic Management Journal 10 399-411.

Hansmann, H. 1996. The ownership of enterprise. The Belknap Press of Harvard University Press, Cambridge, Mass.

Hart, O.D., J. Moore. 1990. Property rights and the nature of the firm. Journal of Political Economy 98 1119-1158.

Hendrikse, G.W.J. 2007. On the coexistence of spot and contract markets: a delivery requirement explanation. European Review of Agricultural Economics 34(2) 137-162.

Hendrikse G.W.J., C.P. Veerman. 2001. Marketing co-operatives: an incomplete contracting perspective. Journal of Agricultural Economics 52(1) 53-64.

Holmström, B.R., P. Milgrom. 1994. The firm as an incentive system. American Economic Review 84(4) 972-991.

Joskow, P.L. 1989. The role of transaction costs economics in antitrust and public utility regulatory policies. Journal of Law, Economics, and Organization 7 53-83.

Klein, B., R.A. Crawford, A.A. Alchian. 1978. Vertical integration, appropriable rents, and the competitive contracting process. Journal of Law and Economics 21 297-326.

Liu, Y., Z. J. Zhang. 2006. The benefits of personalized pricing in a channel. Marketing Science 25(1) 97-105. 
Makadok, R., R. Coff. 2009. Both markets and hierarchy: an incentive-system theory of hybrid governance forms. Academy of Management Review 34(2) 297-319.

Nilsson, J. 1998. The emergence of new organizational models for agricultural cooperatives. Swedish Journal of Agricultural Sciences 28 39-47.

Nourse, E.G. 1922. The economic philosophy of co-operation. American Economic Review 12(4) 577-597.

Perry, M.K. 1989. Vertical integration: determinants and effects. R. Schmalensee, R.D. Willig, eds. Handbook of industrial organization, North Holland, Amsterdam.

Purohit, D. 1997. Dual distribution channels: the competition between rental agencies and dealers, Marketing Science 16(3) 228-245.

Reardon, T., C.P. Timmer, J. Berdegue. 2004. The rapid rise of supermarkets in developing countries: Induced organizational, institutional, and technological change in agrifood systems. Electronic Journal of Agricultural and Development Economics 1(2) http://www.fao.org/es/ESA/ejade/vol_1/vol_1_2.htm.

Shapley, L. 1953 A value for n-person games. H. Kuhn, H., A.W. Tucker, eds. Contributions to the theory of games Vol II, Princeton University Press, Princeton (NJ).

Sutton, J. 1990. Explaining everything, explaining nothing? Game theoretic models in industrial economics. European Economic Review 34 505-512.

USDA Agricultural Cooperative Service. 1993. Cooperative historical statistics. Cooperative Information Report 1 section 26.

Wernerfelt, B. 1994. An efficiency criterion for marketing design. Journal of Marketing Research 31(4) 462-470.

Williamson, O.E. 1985. The Economic Institutions of Capitalism. Free Press, New York.

Zettelmeyer, F. 2000. Expanding to the internet: pricing and communications strategies when firms compete on multiple channels. Journal of Marketing Research 37(3) 292-308. 


\section{Appendix 1: Extensive form}

This appendix consists of three parts. The characteristic functions, the Shapley values, and the extensive form are presented in this appendix.

\section{Characteristic functions}

Three cases regarding investment are distinguished. Consider first the situation where only grower 1 invests. The creation of value requires a coalition consisting of at least (the produce of) grower 1 and (the outlet of) the wholesaler. Table A1.1 presents the characteristic function of the various governance structures. For example, all parties are independent in governance structure I. So, the value A is only generated when at least grower 1 and the wholesaler are present. It implies that only $\mathrm{v}(13)$ and $\mathrm{v}(123)$ are equal to A. All other coalitions have value 0 . Governance structure III reflects the situation of forward integration by grower 1 into wholesaling. The only requirement for the generation of value A by a coalition is that grower 1 is part of the coalition. The change from governance structure I to governance structure III shows the effect of increased ownership over assets.

\begin{tabular}{|c|c|c|c|c|c|c|c|c|}
\hline $\mathbf{x}$ & $\mathbf{G}$ & $\mathbf{v}(\mathbf{1})$ & $\mathbf{v}(\mathbf{2})$ & $\mathbf{v}(\mathbf{3})$ & $\mathbf{v}(\mathbf{1 2})$ & $\mathbf{v}(\mathbf{1 3})$ & $\mathbf{v}(\mathbf{2 3})$ & $\mathbf{v}(\mathbf{1 2 3})$ \\
\hline$(1,0)$ & I & 0 & 0 & 0 & 0 & $\mathrm{~A}$ & 0 & $\mathrm{~A}$ \\
\hline$(1,0)$ & II & 0 & 0 & 0 & 0 & $\mathrm{~A}$ & 0 & $\mathrm{~A}$ \\
\hline$(1,0)$ & III & $\mathrm{A}$ & 0 & 0 & $\mathrm{~A}$ & $\mathrm{~A}$ & 0 & $\mathrm{~A}$ \\
\hline$(1,0)$ & IV & 0 & 0 & 0 & $\mathrm{~A}$ & 0 & 0 & $\mathrm{~A}$ \\
\hline$(1,0)$ & $\mathrm{V}$ & $\mathrm{A}$ & 0 & 0 & $\mathrm{~A}$ & $\mathrm{~A}$ & 0 & $\mathrm{~A}$ \\
\hline
\end{tabular}

Table A1.1: Characteristic function forms when only grower 1 invests

The second case consists of the situation where only grower 2 invests. The characteristic function will not be presented because it is similar to the previous case. Table A1.2 presents the characteristic function for each governance structure when both growers invest. Governance structure I shows the effect of excess supply. The wholesaler adds value to the singleton coalitions $\{1\}$ and $\{2\}$, i.e. $v(13)$ and $\mathrm{v}(23)$ are positive. The difference between $\mathrm{v}(13)=\mathrm{A}$ and $\mathrm{v}(23)=\mathrm{B}$ reflects the heterogeneity between the growers. The equality principle regarding revenues as well as delivery is reflected in the characteristic function of the governance structures II and V. The difference between these two governance structures is due to the difference in power of the wholesaler.

\begin{tabular}{|c|c|c|c|c|c|c|c|c|}
\hline $\mathbf{x}$ & $\mathbf{G}$ & $\mathbf{v}(\mathbf{1})$ & $\mathbf{v}(\mathbf{2})$ & $\mathbf{v}(\mathbf{3})$ & $\mathbf{v}(\mathbf{1 2})$ & $\mathbf{v}(\mathbf{1 3})$ & $\mathbf{v}(\mathbf{2 3})$ & $\mathbf{v}(\mathbf{1 2 3})$ \\
\hline \hline$(1,1)$ & $\mathrm{I}$ & 0 & 0 & 0 & 0 & $\mathrm{~A}$ & $\mathrm{~B}$ & $\mathrm{~A}$ \\
\hline$(1,1)$ & $\mathrm{II}$ & 0 & 0 & 0 & 0 & $(\mathrm{~A}+\mathrm{B}) / 4$ & $(\mathrm{~A}+\mathrm{B}) / 4$ & $(\mathrm{~A}+\mathrm{B}) / 2$ \\
\hline$(1,1)$ & III & $\mathrm{A}$ & 0 & 0 & $\mathrm{~A}$ & $\mathrm{~A}$ & 0 & $\mathrm{~A}$ \\
\hline$(1,1)$ & $\mathrm{IV}$ & 0 & $\mathrm{~B}$ & 0 & $\mathrm{~B}$ & 0 & $\mathrm{~B}$ & $\mathrm{~B}$ \\
\hline$(1,1)$ & $\mathrm{V}$ & $(\mathrm{A}+\mathrm{B}) / 4$ & $(\mathrm{~A}+\mathrm{B}) / 4$ & 0 & $(\mathrm{~A}+\mathrm{B}) / 2$ & $(\mathrm{~A}+\mathrm{B}) / 4$ & $(\mathrm{~A}+\mathrm{B}) / 4$ & $(\mathrm{~A}+\mathrm{B}) / 2$ \\
\hline
\end{tabular}

Table A1.2: Characteristic function forms when both growers invest

\section{Shapley values}

Table A1.3 presents the Shapley values belonging to the characteristic functions of table A1.1. If only grower 1 invests, i.e. $x=(1,0)$, then the incentive to invest for grower 1 in the various governance structures ranks as: 


$$
\mathrm{I}=\mathrm{II}=\mathrm{IV}<\mathrm{III}=\mathrm{V} .
$$

The explanation is straightforward. Ownership over assets determines the distribution of bargaining power completely. Grower 1 owns all the relevant assets in the governance structures III and V. The relevant assets are shared between grower 1 and another party in the governance structures I, II, and IV.

\begin{tabular}{|c|c|c|c|c|}
\hline $\mathbf{x}$ & $\mathbf{G}$ & $\begin{array}{c}\text { Shapley value } \\
\text { grower 1 }\end{array}$ & $\begin{array}{c}\text { Shapley value } \\
\text { grower 2 }\end{array}$ & $\begin{array}{c}\text { Shapley value } \\
\text { wholesaler }\end{array}$ \\
\hline \hline$(1,0)$ & $\mathrm{I}$ & $\mathrm{A} / 2$ & 0 & $\mathrm{~A} / 2$ \\
\hline$(1,0)$ & $\mathrm{II}$ & $\mathrm{A} / 2$ & 0 & $\mathrm{~A} / 2$ \\
\hline$(1,0)$ & $\mathrm{III}$ & $\mathrm{A}$ & 0 & 0 \\
\hline$(1,0)$ & $\mathrm{IV}$ & $\mathrm{A} / 2$ & $\mathrm{~A} / 2$ & 0 \\
\hline$(1,0)$ & $\mathrm{V}$ & $\mathrm{A}$ & 0 & 0 \\
\hline
\end{tabular}

Table A1.3: Shapley values when only grower 1 invests

The Shapley values belonging to the second case will not be presented in a separate table due to the similarity with table A1.3. The ranking of the governance structures in terms of the incentive to invest for grower 2 when only grower 2 invests, i.e. $x=(0,1)$, is:

$$
\mathrm{I}=\mathrm{II}=\mathrm{III}<\mathrm{IV}=\mathrm{V} .
$$

The explanation is identical to the explanation of table A1.3.

If both growers invest, i.e. $x=(1,1)$, then the ranking of the various governance structures is more involved. The Shapley values are presented in table 2 in the main text. It follows from this table that the ranking of the governance structures in terms of the intensity to invest for grower 1 is:

$$
\begin{aligned}
\text { IV } & <\text { I }<\text { II }<\text { V }<\text { III, } & & \text { when } \mathrm{A}<11 \mathrm{~B} / 9 \\
& <\text { II }<\text { I }<\text { V }<\text { III, } & & \text { when } 11 \mathrm{~B} / 9<\mathrm{A}<5 \mathrm{~B} / 3 \\
& <\text { II }<\text { I }<\text { V }<\text { III, } & & \text { when } 5 \mathrm{~B} / 3<\text { A }<7 \mathrm{~B} / 3 \\
& <\text { II }<\text { V }<\text { I }<\text { III, } & & \text { when } 7 \mathrm{~B} / 3<\text { A }<3 \text { B } \\
& <\text { II }<\text { V }<\text { I }<\text { III, } & & \text { when } 3 \mathrm{~B}<\text { A. }
\end{aligned}
$$

Similar, the ranking of the governance structures for grower 2 is:

$$
\begin{aligned}
\text { III }<\text { I } & <\text { II }<\text { V }<\text { IV } & & \text { when } \mathrm{A}<3 \mathrm{~B} \\
& <\text { II }<\text { IV }<\text { V } & & \text { when } 3 \mathrm{~B}<\mathrm{A}<7 \mathrm{~B} \\
& <\text { IV }<\text { II }<\text { V } & & \text { when } \mathrm{A}>7 \mathrm{~B} .
\end{aligned}
$$

\section{Extensive form}

The extensive form is presented in two figures, due to the large number of possible choices that have to be specified. The payoffs in the extensive form reflect the standard incomplete contracting logic that revenues are distributed according to the distribution of bargaining power between all the involved parties (Shapley value), whereas the (relationshipspecific) costs of investment are paid entirely by the investor. 


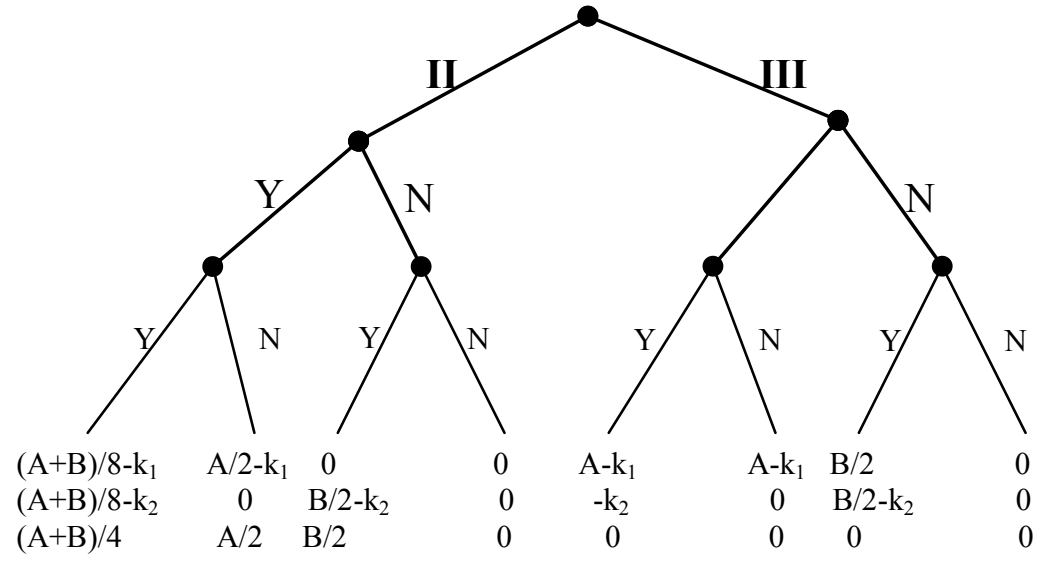

Figure A1.1: Extensive form of governance structure II and III

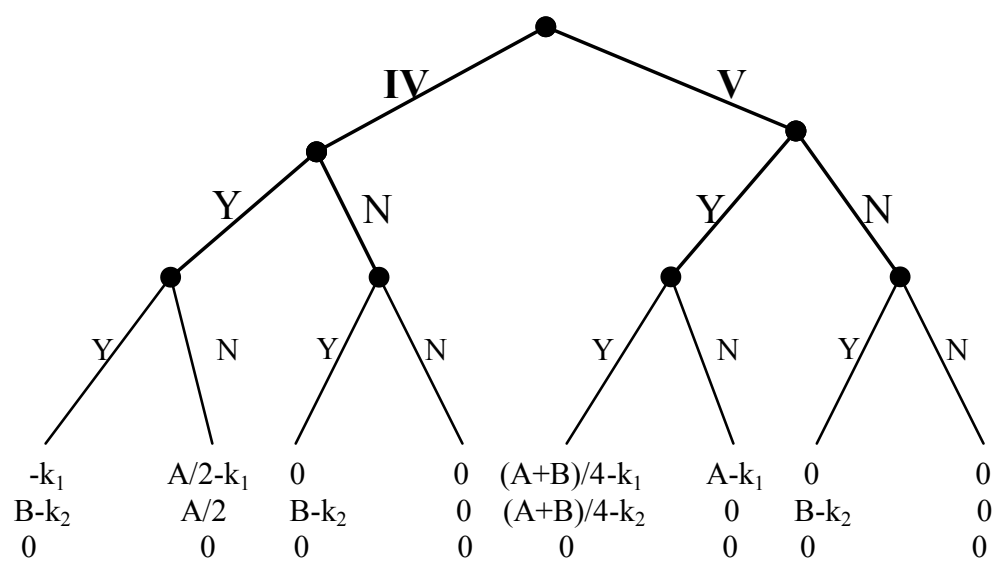

Figure A1.2: Extensive form of governance structure IV and V
Governance structure choice

\section{Grower 1}

Investment choice

\section{Grower 2}

Investment choice

Payoff grower 1

Payoff grower 2

Payoff wholesaler

\section{Governance structure choice}

\section{Grower 1}

Investment choice

\section{Grower 2}

Investment choice

Payoff grower 1

Payoff grower 2

Payoff wholesaler 


\section{Appendix 2: Subgame perfect equilibrium investment choices and payoffs}

This appendix determines the subgame perfect equilibrium investment choices and payoffs. The subgame perfect equilibrium payoffs associated with each governance structure will be presented with a vector consisting of three numbers. The first (second, third) number is the payoff of grower 1 (grower 2, wholesaler). Figure A2.1 ${ }^{20}$ presents the subgame perfect equilibrium choices in the governance structures I, III, IV, while figure A2.2-A2.5 presents these choices in the governance structures II and V.

\begin{tabular}{|c|c|c|c|c|}
\hline \multirow[t]{2}{*}{$\mathrm{k}_{2}$} & \multirow{2}{*}{\multicolumn{2}{|c|}{$\begin{array}{l}\text { I : }\left(\mathrm{A} / 2-\mathrm{k}_{1}, 0, \mathrm{~A} / 2\right) \\
\text { III: }\left(\mathrm{A}-\mathrm{k}_{1}, 0,0\right) \\
\text { IV: }\left(\mathrm{A} / 2-\mathrm{k}_{1}, \mathrm{~A} / 2,0\right)\end{array}$}} & $\begin{array}{l}\text { I: }(0,0,0) \\
\text { III: }\left(A-k_{1}, 0,0\right) \\
\text { IV: }(0.0 .0)\end{array}$ & $\begin{array}{l}\text { I: }(0,0,0) \\
\text { III: }(0,0,0) \\
\text { IV: }(0.0 .0)\end{array}$ \\
\hline & & & $\begin{array}{l}\text { I: }(0,0,0) \\
\text { III: }\left(A-k_{1}, 0,0\right) \\
\text { IV: }(0 . \text { B-k, }, 0)\end{array}$ & $\begin{array}{l}\text { I: }(0,0,0) \\
\text { III: }(0,0,0) \\
\text { IV: }\left(0 .,-k_{2}, 0\right)\end{array}$ \\
\hline & $\begin{array}{l}\text { I: }\left(\mathrm{A} / 2-\mathrm{k}_{1},\right. \\
\text { III: }\left(\mathrm{A}-\mathrm{k}_{1}, \mathrm{C}\right. \\
\text { IV: }(\mathrm{A} / 2-\mathrm{k}\end{array}$ & $\begin{array}{l}A / 2) \\
)(2.0)\end{array}$ & & \\
\hline $\mathrm{B}-\mathrm{A} / 2$ & $\begin{array}{l}\text { I: }\left(\mathrm{A} / 2-\mathrm{k}_{1},\right. \\
\text { III: }\left(\mathrm{A}-\mathrm{k}_{1}, \mathrm{C}\right. \\
\text { IV: }(0 . \mathrm{B}-\mathrm{k}\end{array}$ & $\mathrm{A} / 2)$ & $\begin{array}{l}\text { I: }\left(0, B / 2-k_{2}, B / 2\right) \\
\text { III: }\left(A-k_{1}, 0,0\right) \\
\text { IV: }\left(0 . B-k_{2}, 0\right)\end{array}$ & $\begin{array}{l}\text { I: }\left(0, \mathrm{~B} / 2-\mathrm{k}_{2}, \mathrm{~B} / 2\right) \\
\text { III: }\left(\mathrm{B} / 2, \mathrm{~B} / 2-\mathrm{k}_{2}, 0\right) \\
\text { IV: }\left(0, \mathrm{~B}-\mathrm{k}_{2}, 0\right)\end{array}$ \\
\hline $\mathrm{B} / 6$ & 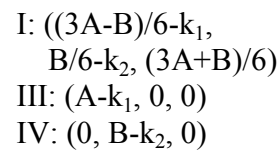 & $\begin{array}{l}\text { I: }\left(0, B / 2-k_{2}, B / 2\right) \\
\text { III: }\left(A-k_{1}, 0,0\right) \\
\text { IV: }\left(0, B-k_{2}, 0\right)\end{array}$ & & \\
\hline
\end{tabular}

Figure A2.1: Subgame perfect equilibrium payoffs regarding the governance structures I, III and IV

The demarcation of the areas of the various subgame perfect equilibrium investment choices of the growers in the governance structures II and V depend on the extent of member heterogeneity. Figures A2.2-4 distinguish the various cases. ${ }^{21}$ Figure A2.5 summarizes these three cases.

\footnotetext{
${ }^{20}$ Figure $\mathrm{A} 2.1$ depicts the situation $\mathrm{B}<\mathrm{A} / 2$. The distinction between the intervals $\mathrm{B}<\mathrm{A} / 2$ and $\mathrm{B}>\mathrm{A} / 2$ is only relevant regarding governance structure IV due to the allocation of priority access to grower 2 in this governance structure.

${ }^{21}$ The two dotted lines reflect that whether $\mathrm{B} / 2$ and $\mathrm{B}$ are smaller or larger than $(\mathrm{A}+\mathrm{B}) / 8$ and $/$ or $(\mathrm{A}+\mathrm{B}) / 4$ depends on the level of product differentiation.
} 


\begin{tabular}{|c|c|c|c|c|c|}
\hline \multirow{3}{*}{$\begin{array}{r}(\mathrm{A}+\mathrm{B}) / 4 \\
\mathrm{~B} / 2 \\
(\mathrm{~A}+\mathrm{B}) / 8\end{array}$} & \multicolumn{3}{|c|}{$\begin{array}{l}\text { II: }\left(\mathrm{A} / 2-\mathrm{k}_{1}, 0, \mathrm{~A} / 2\right) \\
\mathrm{V}:\left(\mathrm{A}-\mathrm{k}_{1}, 0,0\right)\end{array}$} & $\begin{array}{l}\text { II: }(0,0,0) \\
\text { V: }\left(A-k_{1}, 0,0\right)\end{array}$ & $\begin{array}{l}\text { II: }(0,0,0) \\
\text { V: }(0,0,0)\end{array}$ \\
\hline & \multicolumn{2}{|c|}{$\begin{array}{l}\text { II: }\left(A / 2-k_{1}, 0, A / 2\right) \\
V:\left((A+B) / 4-k_{1},(A+B) / 4-k_{2}, 0\right)\end{array}$} & \multirow{2}{*}{$\begin{array}{l}\text { II: }\left(\mathrm{A} / 2-\mathrm{k}_{1}, 0, \mathrm{~A} / 2\right) \\
\mathrm{V}:\left(0, \mathrm{~B}-\mathrm{k}_{2}, 0\right)\end{array}$} & \multicolumn{2}{|c|}{$\begin{array}{l}\text { II: }(0,0,0) \\
\text { V: }\left(0, B-k_{2}, 0\right)\end{array}$} \\
\hline & $\begin{array}{l}\text { II: }\left((\mathrm{A}+\mathrm{B}) / 8-\mathrm{k}_{1},\right. \\
\left.(\mathrm{A}+\mathrm{B}) / 8-\mathrm{k}_{2},(\mathrm{~A}+\mathrm{B}) / 4\right) \\
\mathrm{V}:\left((\mathrm{A}+\mathrm{B}) / 4-\mathrm{k}_{1},\right. \\
\left.(\mathrm{A}+\mathrm{B}) / 4-\mathrm{k}_{2}, 0\right)\end{array}$ & $\begin{array}{l}\text { II: }\left(0, \mathrm{~B} / 2-\mathrm{k}_{2}, \mathrm{~B} / 2\right) \\
\text { V: }\left((\mathrm{A}+\mathrm{B}) / 4-\mathrm{k}_{1},\right. \\
\left.(\mathrm{A}+\mathrm{B}) / 4-\mathrm{k}_{2}, 0\right)\end{array}$ & & \multicolumn{2}{|c|}{$\begin{array}{l}\text { II: }\left(0, \mathrm{~B} / 2-\mathrm{k}_{2}, \mathrm{~B} / 2\right) \\
\text { V: }\left(0, \mathrm{~B}-\mathrm{k}_{2}, 0\right)\end{array}$} \\
\hline
\end{tabular}

Figure A2.2: Subgame perfect equilibrium payoffs for the governance structures II and V when A $<3 \mathrm{~B}$

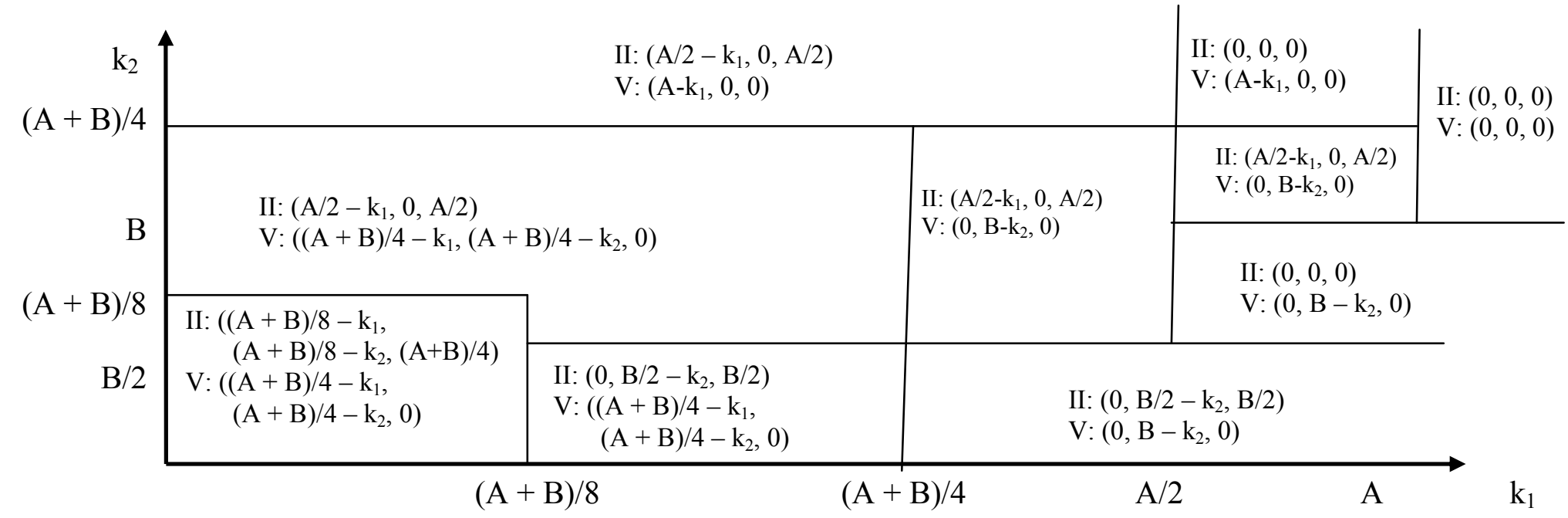

Figure A2.3: Subgame perfect equilibrium payoffs for the governance structures II and V when $3 \mathrm{~B}<\mathrm{A}<7 \mathrm{~B}$

\begin{tabular}{|c|c|c|c|c|c|}
\hline \multirow{2}{*}{$(\mathrm{A}+\mathrm{B}) / 4$} & \multicolumn{2}{|c|}{$\begin{array}{l}\text { II: }\left(\mathrm{A} / 2-\mathrm{k}_{1}, 0, \mathrm{~A} / 2\right) \\
\mathrm{V}:\left(\mathrm{A}-\mathrm{k}_{1}, 0,0\right)\end{array}$} & & $\left|\begin{array}{l}\text { II: }(0,0,0) \\
\text { V: }\left(A-k_{1}, 0,0\right)\end{array}\right|$ & \multirow{2}{*}{$\begin{array}{l}\text { II: }(0,0,0) \\
\text { V: }(0,0,0)\end{array}$} \\
\hline & \multicolumn{2}{|c|}{$\begin{array}{l}\text { II: }\left(\mathrm{A} / 2-\mathrm{k}_{1}, 0, \mathrm{~A} / 2\right) \\
\mathrm{V}:\left((\mathrm{A}+\mathrm{B}) / 4-\mathrm{k}_{1},(\mathrm{~A}+\mathrm{B}) / 4-\mathrm{k}_{2}, 0\right)\end{array}$} & $\begin{array}{l}\text { II: }\left(\mathrm{A} / 2-\mathrm{k}_{1}, 0, \mathrm{~A} / 2\right) \\
\mathrm{V}:\left(0, \mathrm{~B}-\mathrm{k}_{2}, 0\right)\end{array}$ & & \\
\hline $\mathrm{B} / 2$ & $\begin{array}{l}\mathrm{II}:\left((\mathrm{A}+\mathrm{B}) / 8-\mathrm{k}_{1},\right. \\
\left.\quad(\mathrm{A}+\mathrm{B}) / 8-\mathrm{k}_{2},(\mathrm{~A}+\mathrm{B}) / 4\right) \\
\mathrm{V}:\left((\mathrm{A}+\mathrm{B}) / 4-\mathrm{k}_{1},\right. \\
\left.\quad(\mathrm{A}+\mathrm{B}) / 4-\mathrm{k}_{2}, 0\right)\end{array}$ & $\begin{array}{l}\text { II: }\left(0, B / 2-k_{2}, B / 2\right) \\
\text { V: }\left((A+B) / 4-k_{1},\right. \\
\left.\quad(A+B) / 4-k_{2}, 0\right)\end{array}$ & $\begin{array}{l}\text { II: }\left(0, \mathrm{~B} / 2-\mathrm{k}_{2}, \mathrm{~B} / 2\right) \\
\text { V: }\left(0, \mathrm{~B}-\mathrm{k}_{2}, 0\right)\end{array}$ & \multicolumn{2}{|c|}{$\begin{array}{l}\text { II: }(0,0,0) \\
\text { V: }\left(0, B-k_{2}, 0,0\right)\end{array}$} \\
\hline
\end{tabular}

Figure A2.4: Subgame perfect equilibrium payoffs for the governance structures II and V when A>7B 


\begin{tabular}{|c|c|c|c|c|c|}
\hline \multirow{3}{*}{$\begin{array}{r}(\mathrm{A}+\mathrm{B}) / 4 \\
\mathrm{~B} \\
(\mathrm{~A}+\mathrm{B}) / 8 \\
\mathrm{~B} / 2\end{array}$} & \multicolumn{3}{|c|}{$\begin{array}{l}\text { II: }\left(\mathrm{A} / 2-\mathrm{k}_{1}, 0, \mathrm{~A} / 2\right) \\
\mathrm{V}:\left(\mathrm{A}-\mathrm{k}_{1}, 0,0\right)\end{array}$} & \multirow{3}{*}{$\begin{array}{l}\text { II: }(0,0,0) \\
\begin{array}{l}\text { V: }\left(\mathrm{A}-\mathrm{k}_{1}, 0,0\right) \\
\\
\text { II: }(0,0, \\
\text { V: }(0, \mathrm{~B}-\mathrm{k}\end{array}\end{array}$} & \multirow{3}{*}{$\begin{array}{l}\text { II: }(0,0,0) \\
\text { V: }(0,0,0)\end{array}$} \\
\hline & \multicolumn{2}{|c|}{$\begin{array}{l}\text { II: }\left(\mathrm{A} / 2-\mathrm{k}_{1}, 0, \mathrm{~A} / 2\right) \\
\mathrm{V}:\left((\mathrm{A}+\mathrm{B}) / 4-\mathrm{k}_{1},(\mathrm{~A}+\mathrm{B}) / 4-\mathrm{k}_{2}, 0\right)\end{array}$} & $\begin{array}{l}\text { II: }\left(\mathrm{A} / 2-\mathrm{k}_{1}, 0, \mathrm{~A} / 2\right) \\
\mathrm{V}:\left(0, \mathrm{~B}-\mathrm{k}_{2}, 0\right)\end{array}$ & & \\
\hline & $\begin{array}{l}\text { II: ((A+B)/8- } \mathrm{k}_{1}, \\
(\mathrm{~A}+\mathrm{B}) / 8-\mathrm{k}_{2}, \\
(\mathrm{~A}+\mathrm{B}) / 4) \\
\text { V: }\left((\mathrm{A}+\mathrm{B}) / 4-\mathrm{k}_{1},\right. \\
\left.(\mathrm{A}+\mathrm{B}) / 4-\mathrm{k}_{2}, 0\right)\end{array}$ & $\begin{array}{l}\text { II: }\left(0, \mathrm{~B} / 2-\mathrm{k}_{2}, \mathrm{~B} / 2\right) \\
\text { V: }\left((\mathrm{A}+\mathrm{B}) / 4-\mathrm{k}_{1},\right. \\
\left.(\mathrm{A}+\mathrm{B}) / 4-\mathrm{k}_{2}, 0\right)\end{array}$ & $\begin{array}{l}\text { II: }\left(0, \mathrm{~B} / 2-\mathrm{k}_{2}, \mathrm{~B} / 2\right) \\
\mathrm{V}:\left(0, \mathrm{~B}-\mathrm{k}_{2}, 0\right)\end{array}$ & & \\
\hline
\end{tabular}

Figure A2.5: Subgame perfect equilibrium payoffs regarding the governance structures II and V

Figure A2.6 presents the subgame perfect equilibrium payoffs. It is the result of merging the figures A2.1-A2.5. The precise demarcation of the various areas depends on the specific governance structure and the extent of member heterogeneity. The subgame perfect equilibrium payoffs of the governance structures I, II, and V in the area characterized by $\mathrm{k}_{1}<\mathrm{A} / 2$ and $\mathrm{k}_{2}<\mathrm{B} / 6$ depends on the difference between $\mathrm{A}$ and $\mathrm{B}$. It follows from figure $\mathrm{A} 2.1$ that the subgame perfect equilibrium payoffs in governance structure I are equal to $\left((3 \mathrm{~A}-2 \mathrm{~B}) / 6-\mathrm{k}_{1}, \mathrm{~B} / 6-\mathrm{k}_{2},(3 \mathrm{~A}+\mathrm{B}) / 6\right)$ when $\mathrm{k}_{1}<(3 \mathrm{~A}-2 \mathrm{~B}) / 6$ and $\left(0, \mathrm{~B} / 2-\mathrm{k}_{2}, \mathrm{~B} / 2\right)$ when $\mathrm{k}_{1}>(3 \mathrm{~A}-$ $2 B) / 6$. Similarly, it follows from figure A2.5 that the subgame perfect equilibrium payoffs in governance structure II (V) depends on $\mathrm{k}_{1}$ being smaller or larger than $(\mathrm{A}+\mathrm{B}) / 8((\mathrm{~A}+\mathrm{B}) / 4)$. The subgame perfect equilibrium payoffs are equal to one of two possible vectors of payoffs. These two possibilities are presented by the '/' between two vectors in this area in figure 4 . The switch in subgame perfect equilibrium payoffs in these governance structures occurs at $\mathrm{k}_{1}$ being equal to either $(3 \mathrm{~A}-2 \mathrm{~B}) / 6$, or $(\mathrm{A}+\mathrm{B}) / 8$, or $(\mathrm{A}+\mathrm{B}) / 4$. Solid lines demarcate areas being present for all parameter values, whereas dotted lines delineate areas being present only for certain values of the parameters $A$ and $B$. The equilibrium payoffs in figure 4 entail also the subgame perfect equilibrium investment levels because each payoff vector corresponds with a specific path of branches, i.e. investment decisions, in the extensive form. 


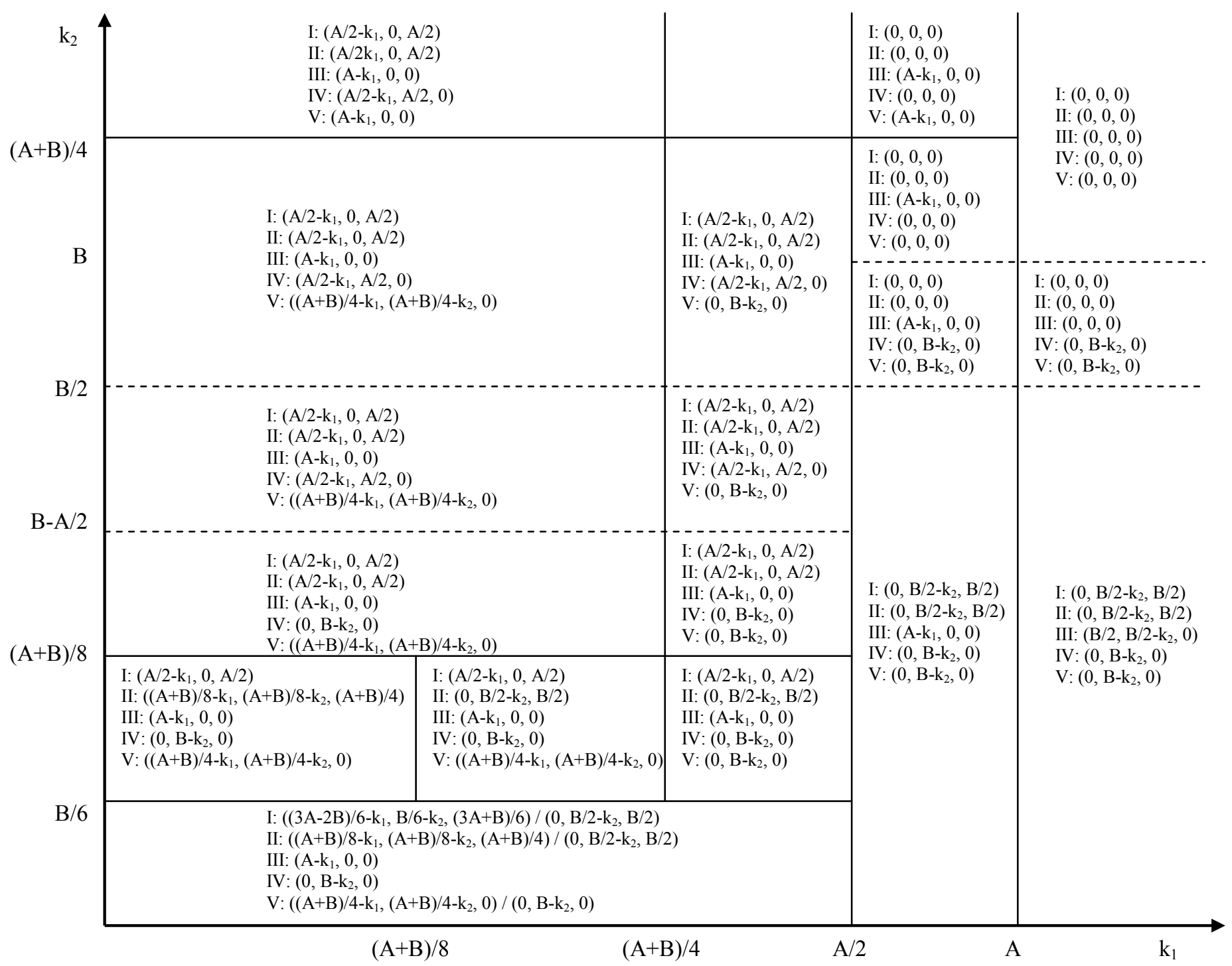

Figure A2.6: Subgame perfect equilibrium payoffs 


\section{Appendix 3: Efficient governance structure choice}

The figures A2.1 and A2.5 determine the efficient governance structure choices in the class $\{$ I, III, IV $\}$ for all levels of asset specificity. Four cases have to be distinguished. They are identified in table A3.1.

\begin{tabular}{|l|l|l|}
\hline & \multicolumn{1}{|c|}{ Horizontal axis } & Vertical axis \\
\hline $\mathrm{A}<4 \mathrm{~B} / 3$ & $\mathrm{~A}-\mathrm{B}<(3 \mathrm{~A}-2 \mathrm{~B}) / 6<\mathrm{A} / 2$ & $\mathrm{~B} / 6<\mathrm{B}-\mathrm{A} / 2$ \\
$4 \mathrm{~B} / 3<\mathrm{A}<5 \mathrm{~B} / 3$ & $(3 \mathrm{~A}-2 \mathrm{~B}) / 6<\mathrm{A}-\mathrm{B}<\mathrm{A} / 2$ & $\mathrm{~B} / 6<\mathrm{B}-\mathrm{A} / 2$ \\
$5 \mathrm{~B} / 3<\mathrm{A}<2 \mathrm{~B}$ & $(3 \mathrm{~A}-2 \mathrm{~B}) / 6<\mathrm{A}-\mathrm{B}<\mathrm{A} / 2$ & $\mathrm{~B}-\mathrm{A} / 2<\mathrm{B} / 6$ \\
$\mathrm{~A}>2 \mathrm{~B}$ & $(3 \mathrm{~A}-2 \mathrm{~B}) / 6<\mathrm{A} / 2<\mathrm{A}-\mathrm{B}$ & $\mathrm{B}-\mathrm{A} / 2<\mathrm{B} / 6$ \\
\hline
\end{tabular}

Table A3.1: Four cases regarding the efficient governance structure choices in the class \{I, III, IV\}

The efficient governance structures in these cases are presented in the figures A3.1A3.4. Figure A3.5 summarizes the figures A3.1-A3.4.

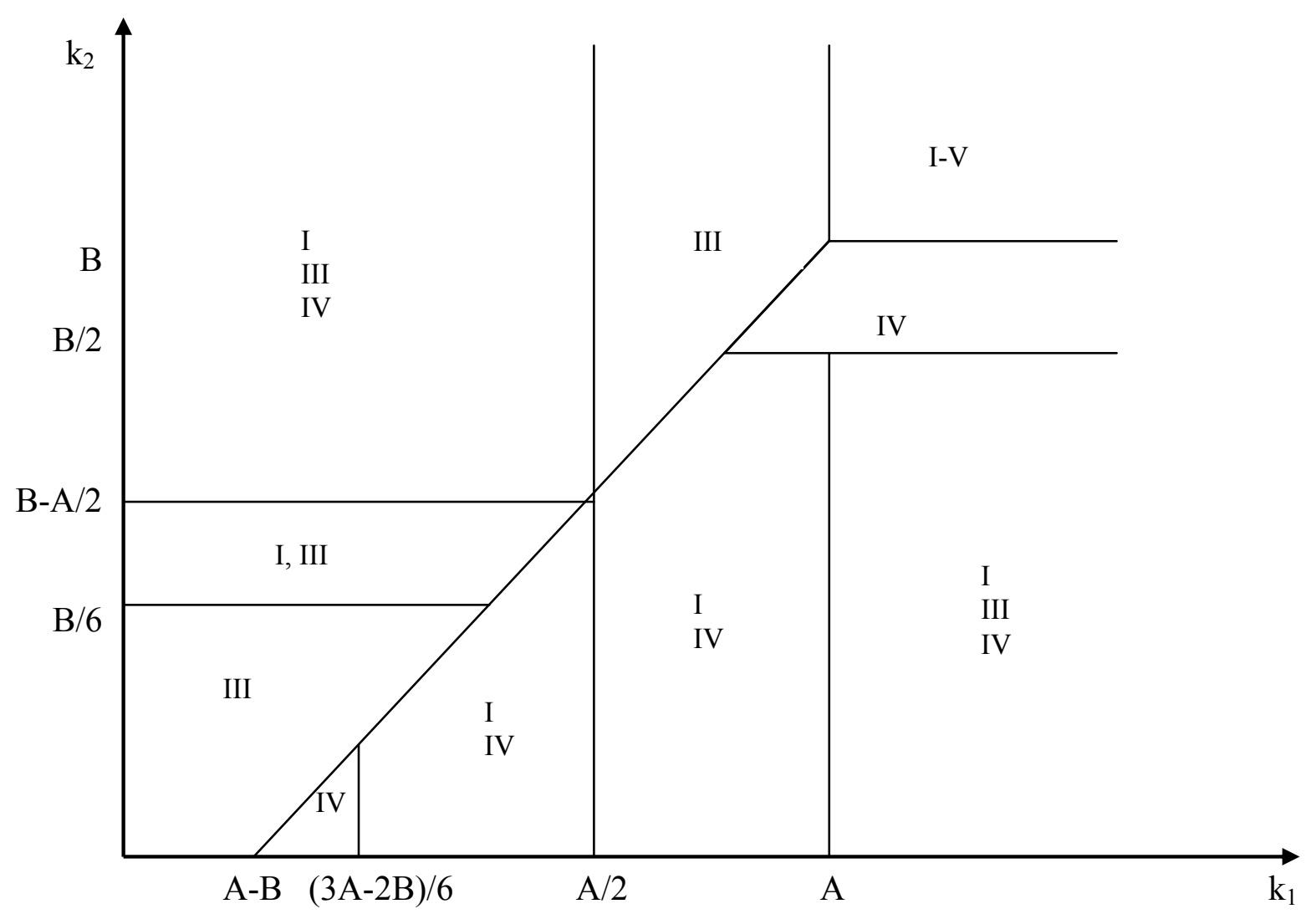

Figure A3.1: Efficient governance structures in the class $\{\mathrm{I}, \mathrm{III}, \mathrm{IV}\}$ when $\mathrm{A}<4 \mathrm{~B} / 3$ 


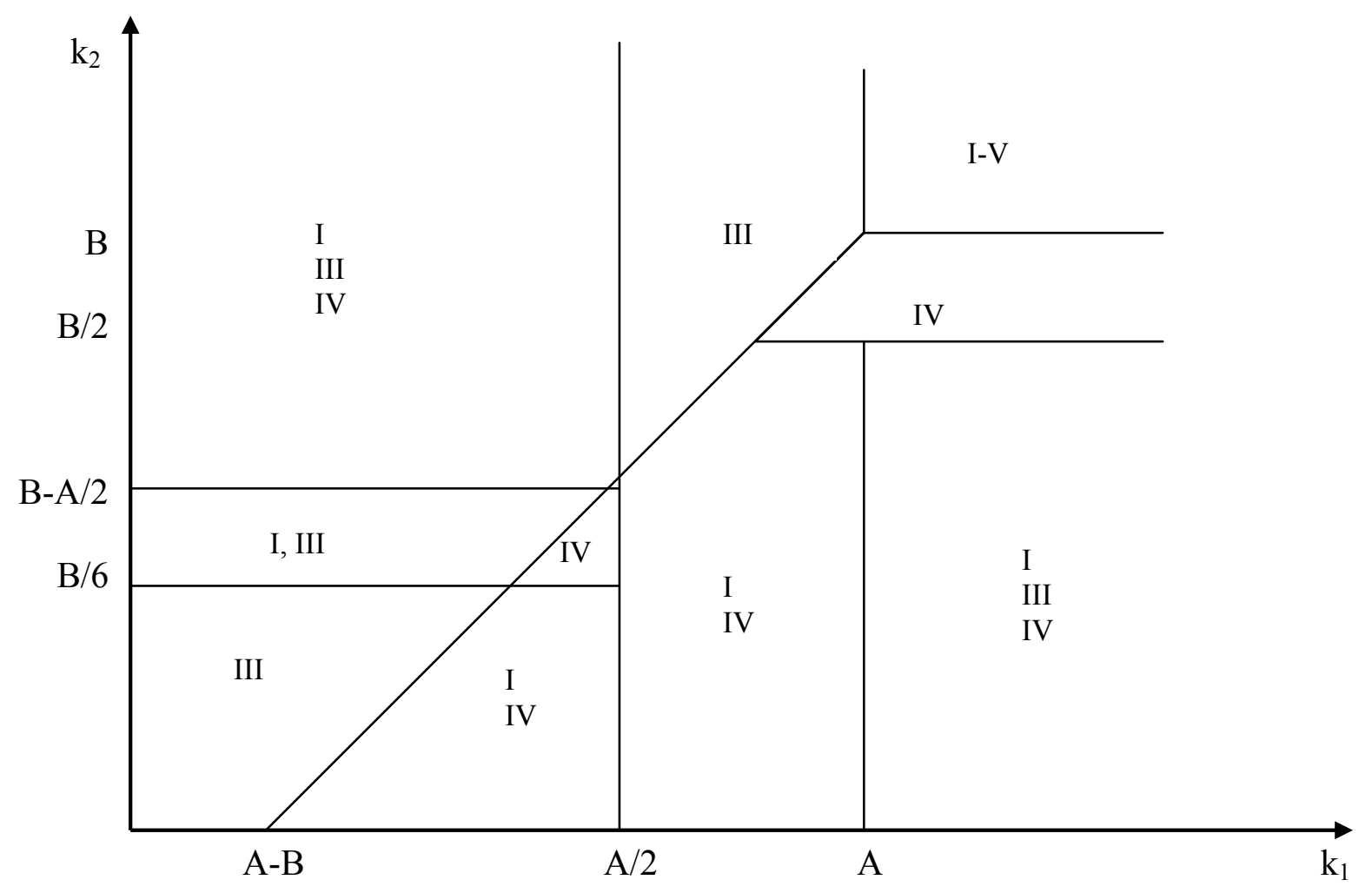

Figure A3.2: Efficient governance structures in the class $\{$ I, III, IV $\}$ when $4 B / 3<A<5 B / 3$

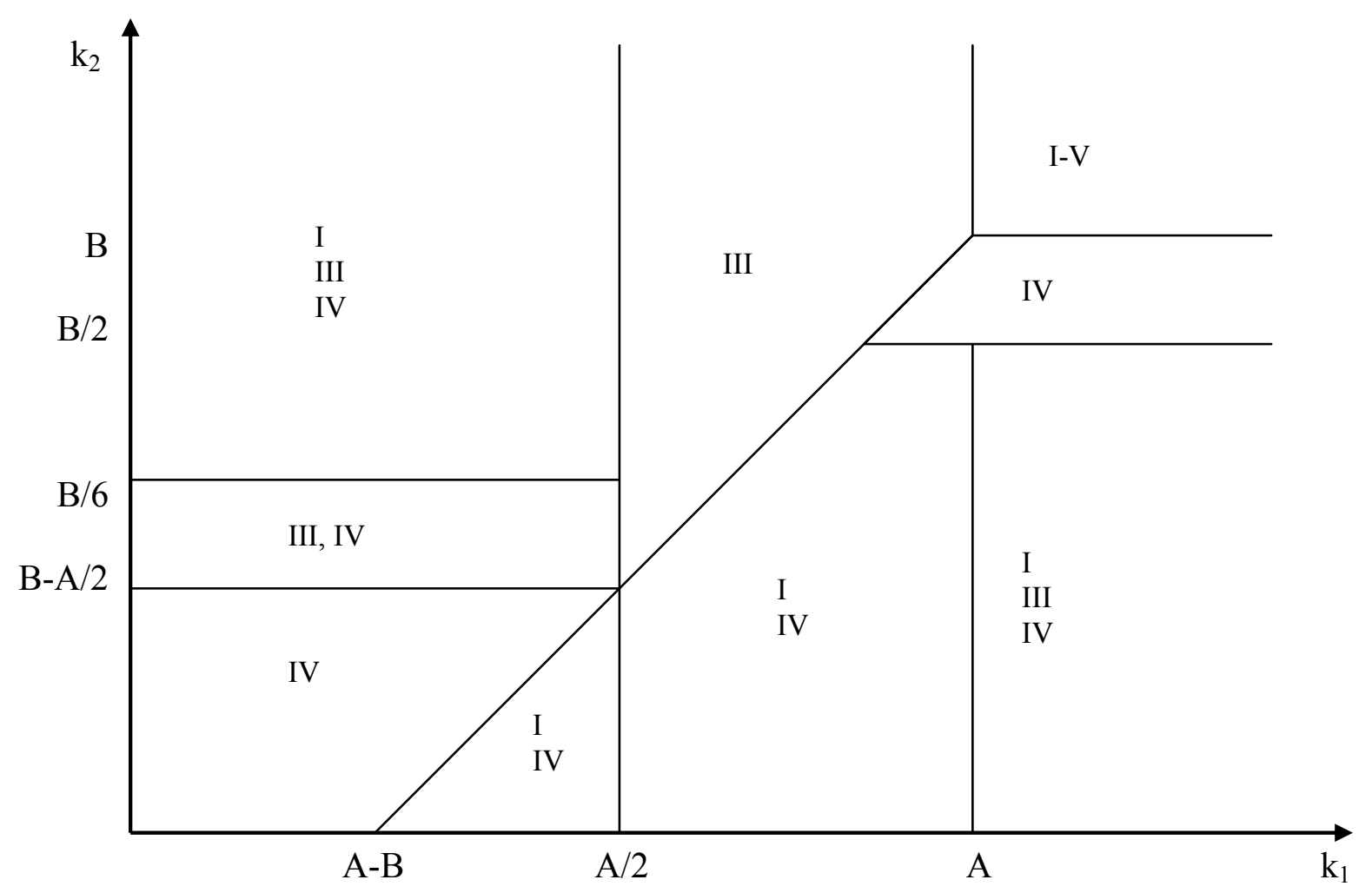

Figure A3.3: Efficient governance structure choices in the class $\{$ I, III, IV $\}$ when $5 B / 3<A<$ 2B 


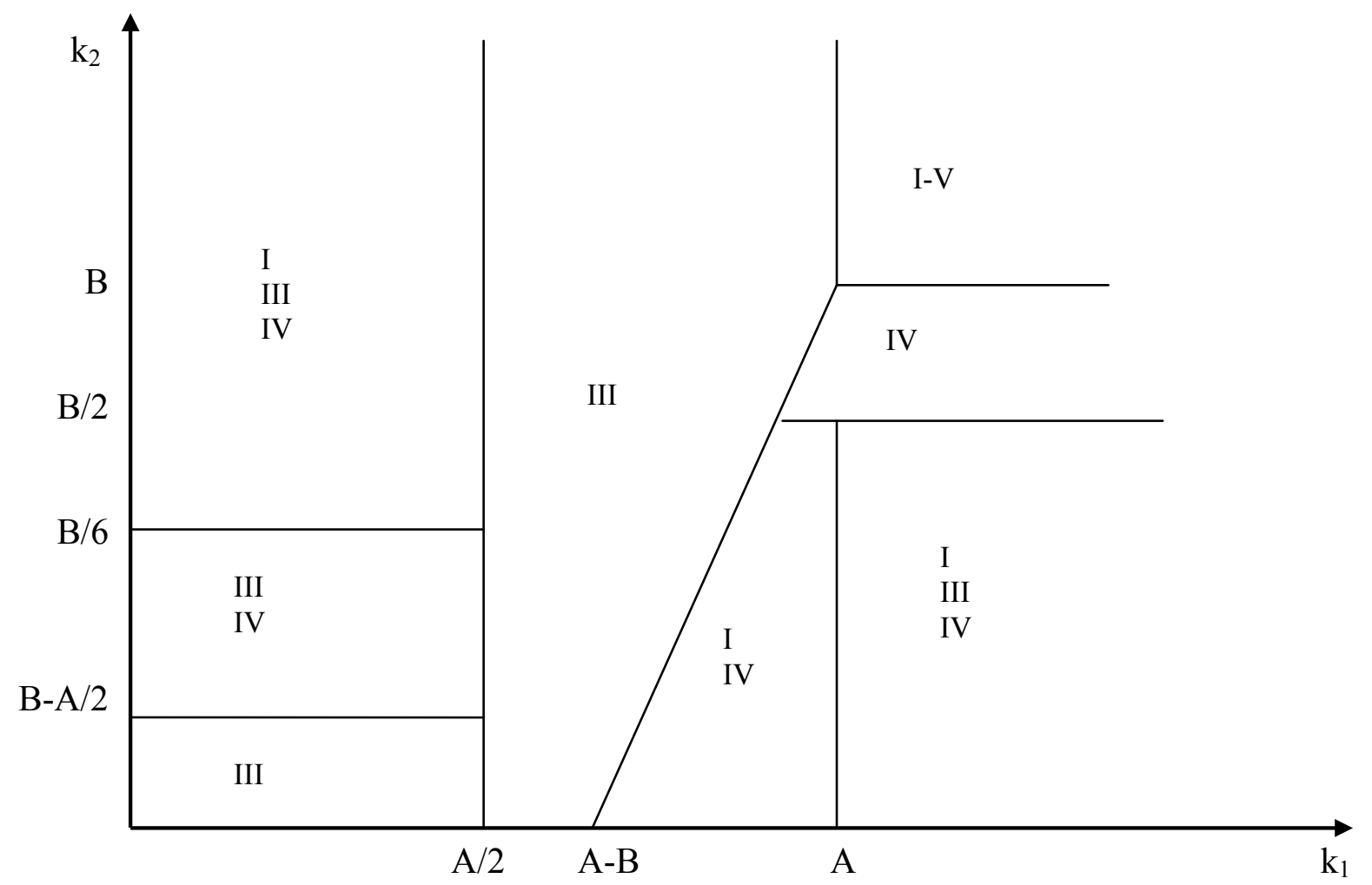

Figure A3.4: Efficient governance structure choices in the class $\{$ I, III, IV $\}$ when A>2B

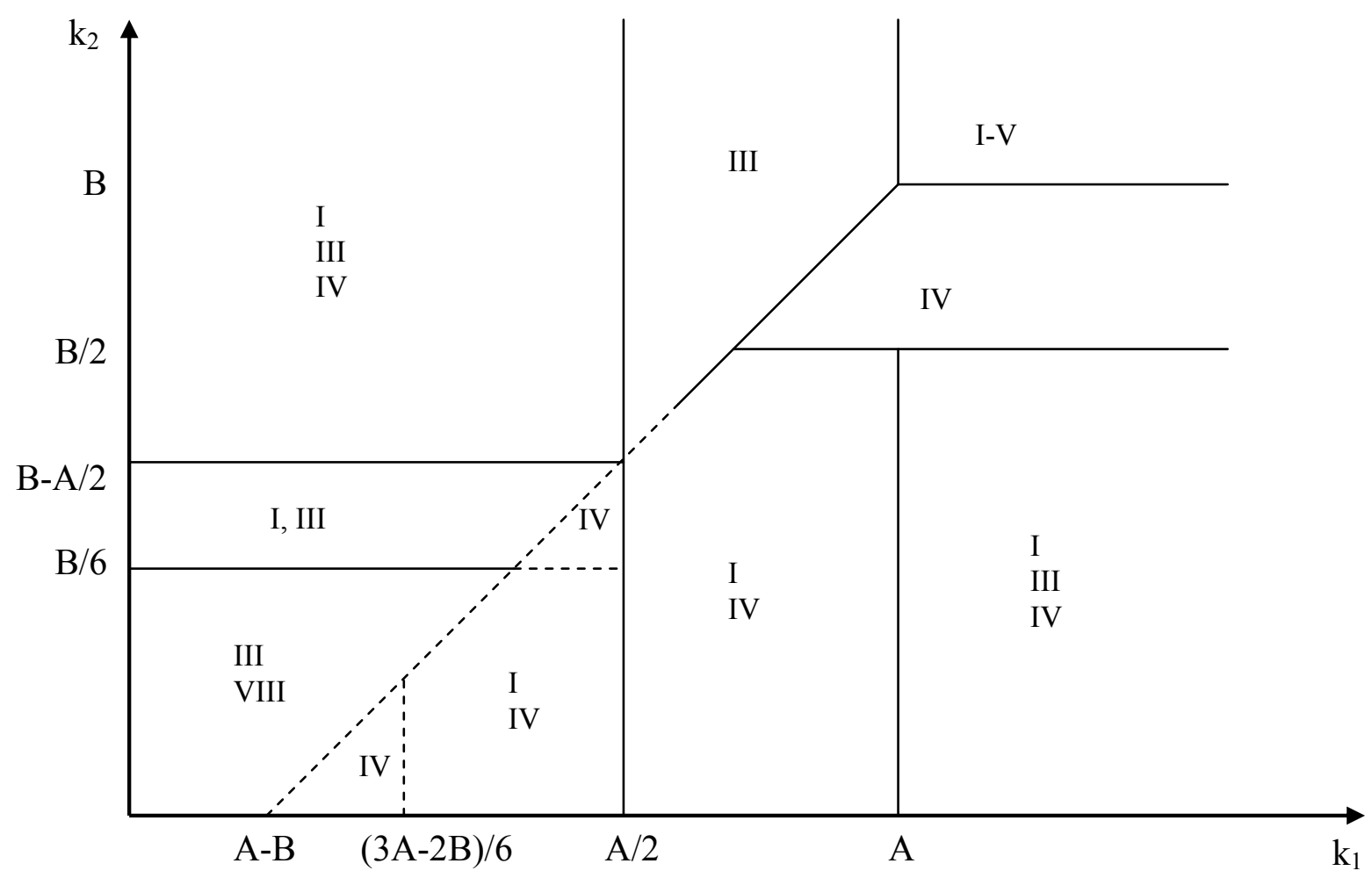

Figure A3.5: Efficient governance structure choices in the class $\{$ I, III, IV $\}$ 
Figure A2.5 determines the efficient governance structure choices in the class $\{$ II, V\} for all levels of asset specificity. Five cases have to be distinguished, which are identified in table A3.2. Three points on the $45^{\circ}$ line thru the point $(A-B, 0)$ distinguish these cases.

\begin{tabular}{|l|l|l|l|}
\hline & $(\mathrm{A}-\mathrm{B}, 0)$ with $\mathrm{A}-\mathrm{B} \epsilon$ & $(\mathrm{A} / 2, \mathrm{~B}-\mathrm{A} / 2)$ with $\mathrm{B}-\mathrm{A} / 2 \epsilon$ & $(\mathrm{A}, \mathrm{B})$ with $\mathrm{B} \epsilon$ \\
\hline $\mathrm{A}<9 \mathrm{~B} / 7$ & $(0,(\mathrm{~A}+\mathrm{B}) / 8)$ & $((\mathrm{A}+\mathrm{B}) / 8, \mathrm{~B} / 2)$ & $((\mathrm{A}+\mathrm{B}) / 4, \infty)$ \\
\hline $9 \mathrm{~B} / 7<\mathrm{A}<7 \mathrm{~B} / 5$ & $((\mathrm{~A}+\mathrm{B}) / 8,(\mathrm{~A}+\mathrm{B}) / 4)$ & $((\mathrm{A}+\mathrm{B}) / 8, \mathrm{~B} / 2)$ & $((\mathrm{A}+\mathrm{B}) / 4, \infty)$ \\
\hline $7 \mathrm{~B} / 5<\mathrm{A}<5 \mathrm{~B} / 3$ & $((\mathrm{~A}+\mathrm{B}) / 8,(\mathrm{~A}+\mathrm{B}) / 4)$ & $(0,(\mathrm{~A}+\mathrm{B}))$ & $((\mathrm{A}+\mathrm{B}) / 4, \infty)$ \\
\hline $5 \mathrm{~B} / 3<\mathrm{A}<3 \mathrm{~B}$ & $(\mathrm{~A}+\mathrm{B}) / 4, \mathrm{~A} / 2)$ & $(0,(\mathrm{~A}+\mathrm{B}) / 8)$ & $((\mathrm{A}+\mathrm{B}) / 4, \infty)$ \\
\hline $\mathrm{A}>3 \mathrm{~B}$ & $(\mathrm{~A} / 2, \mathrm{~A})$ & $(0,(\mathrm{~A}+\mathrm{B}) / 8)$ & $((\mathrm{A}+\mathrm{B}) / 8,(\mathrm{~A}+\mathrm{B}) / 4)$ \\
\hline
\end{tabular}

Table A3.2: Five cases regarding the efficient governance structure choices in the class $\{$ II, V\}

Figure A3.6 presents the summary of the five cases in terms of efficient governance structure choices. There are a few areas where there is no efficient governance structure in the class $\{\mathrm{II}, \mathrm{V}\}$, which is indicated by '-'. One of these areas is characterized by both levels of asset specificity being low. There will be overinvestment. The other areas with '-' have always one grower producing, but it is the wrong one.

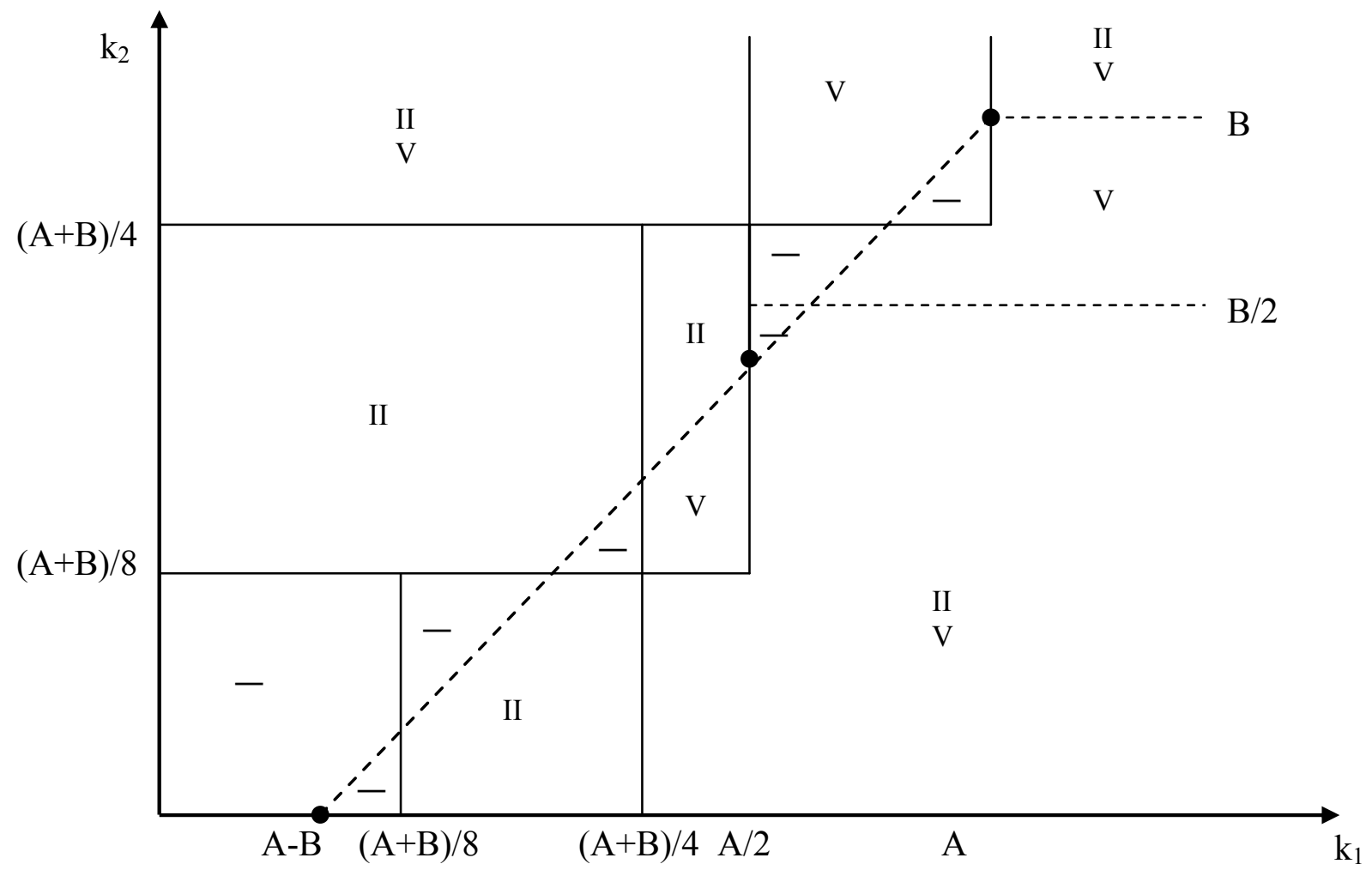

Figure A3.6: Efficient governance structure choices in the class $\{$ II, V\} 
The explanation of the efficient governance structures in the class $\{\mathrm{II}, \mathrm{V}\}$ is straightforward. If the levels of $\mathrm{k}_{1}$ and $\mathrm{k}_{2}$ are to the right of the $45^{\circ}$ line thru $(\mathrm{A}-\mathrm{B}, 0)$, then the costs of investment are sufficiently high that grower 1 does not invest. This makes the market for grower 2 attractive enough to invest. A similar explanation holds for the efficient governance structures to the left of this $45^{\circ}$ line.

Merging the figures A3.6 and A3.7 into figure 5, where

$$
\begin{aligned}
& \mathrm{X} \equiv \min ((3 \mathrm{~A}-2 \mathrm{~B}) / 6,(\mathrm{~A}+\mathrm{B}) / 8) \\
& \mathrm{Z} \equiv \max ((\mathrm{A}+\mathrm{B}) / 4,(3 \mathrm{~A}-2 \mathrm{~B}) / 6) \\
& \mathrm{Y} \equiv\{(3 \mathrm{~A}-2 \mathrm{~B}) / 6,(\mathrm{~A}+\mathrm{B}) / 8,(\mathrm{~A}+\mathrm{B}) / 4\} \backslash\{\mathrm{X}, \mathrm{Z}\}
\end{aligned}
$$

The value of $\mathrm{X}, \mathrm{Y}$, and $\mathrm{Z}$ depends therefore on $\mathrm{A}$ and $\mathrm{B}$. Three cases are distinguished in table A3.3.

\begin{tabular}{|c|c|c|c|}
\hline & $(3 \mathrm{~A}-2 \mathrm{~B}) / 6$ & $(\mathrm{~A}+\mathrm{B}) / 8$ & $(\mathrm{~A}+\mathrm{B}) / 4$ \\
\hline $\mathrm{A}<11 \mathrm{~B} / 9$ & $\mathrm{X}$ & $\mathrm{Y}$ & $\mathrm{Z}$ \\
\hline $11 \mathrm{~B} / 9<\mathrm{A}<7 \mathrm{~B} / 3$ & $\mathrm{Y}$ & $\mathrm{X}$ & $\mathrm{Z}$ \\
\hline $\mathrm{A}>7 \mathrm{~B} / 3$ & $\mathrm{Z}$ & $\mathrm{X}$ & $\mathrm{Y}$ \\
\hline
\end{tabular}

Table A3.3: Three cases regarding the values of $\mathrm{X}, \mathrm{Y}$ and $\mathrm{Z}$

The efficient governance structure choice for $\mathrm{X}<\mathrm{k}_{1}<\mathrm{Y}$ and $\mathrm{k}_{2}<\mathrm{B} / 6$ is

$$
\begin{aligned}
\mathrm{I} / \mathrm{II}= & \mathrm{I} \text { when }(3 \mathrm{~A}-2 \mathrm{~B}) / 6<(\mathrm{A}+\mathrm{B}) / 8 \\
& \mathrm{II} \text { when }(3 \mathrm{~A}-2 \mathrm{~B}) / 6>(\mathrm{A}+\mathrm{B}) / 8 .
\end{aligned}
$$

The efficient governance structure choice for $\mathrm{Y}<\mathrm{k}_{1}<\mathrm{Z}$ and $\mathrm{k}_{2}<\mathrm{B} / 6$ is II and

$$
\begin{aligned}
\mathrm{I} / \mathrm{V}= & \mathrm{I} \text { when }(3 \mathrm{~A}-2 \mathrm{~B}) / 6<(\mathrm{A}+\mathrm{B}) / 4 \\
& \mathrm{~V} \text { when }(3 \mathrm{~A}-2 \mathrm{~B}) / 6>(\mathrm{A}+\mathrm{B}) / 4 .
\end{aligned}
$$




\section{Publications in the ERIM Report Series Research* in Management}

\section{ERIM Research Program: "Organizing for Performance"}

2011

Chain Interdependencies, Measurement Problems, and Efficient Governance Structure:

Cooperatives versus Publicly Listed Firms

Li Feng and George Hendrikse

ERS-2011-001-ORG

http://hdl.handle.net/1765/22720

Using a Relational Models Perspective to Understand Normatively Appropriate Conduct in Ethical Leadership

Steffen R. Giessner and Niels van Quaquebeke

ERS-2011-002-ORG

http://hdl.handle.net/1765/22721

Tango in the Dark: The Interplay of Leader's and Follower's Level of Self-Construal and its Impact on Ethical Leadership Suzanne van Gils, Niels van Quaquebeke, and Daan van Knippenberg

ERS-2011-005-ORG

http://hdl.handle.net/1765/22724

Pooling, Access, and Countervailing Power in Channel Governance

George Hendrikse

ERS-2011-009-ORG

http://hdl.handle.net/1765/22815

* A complete overview of the ERIM Report Series Research in Management:

https://ep.eur.nl/handle/1765/1

ERIM Research Programs:

LIS Business Processes, Logistics and Information Systems

ORG Organizing for Performance

MKT Marketing

F\&A Finance and Accounting

STR Strategy and Entrepreneurship 